\title{
Using seasonal landscape models to predict space use and migratory patterns of an arctic ungulate
}

\author{
A. P. Baltensperger ${ }^{*}$ and K. Joly
}

\begin{abstract}
Background: Caribou in the Western Arctic Herd undertake one of the longest, remaining intact migrations of terrestrial mammals in the world. They are also the most important subsistence resource for many northern rural residents, who rely on the caribou's migratory movements to bring them near for harvest. Migratory geography has never been static, but subsistence harvesters have reported recent shifts in migration away from areas where they traditionally occurred. The reasons behind these changes are not well-understood, but may be related to rapid climate change and anthropogenic disturbances.

Methods: To predict changes in distribution and shifting migratory areas over the past decade, we used GPS telemetry data from adult females to develop predictive ecological niche models of caribou across northwestern Alaska. We employed the machine-learning algorithm, TreeNet, to analyze interactive, multivariate relationships between telemetry locations and 37 spatial environmental layers and to predict the distributions of caribou during spring, calving season, insect-harassment season, late summer, fall, and winter from 2009 to 2017. Model results were analyzed to identify regions of repeated predicted use, quantify mean longitude, predict land cover selection, and track migratory changes over time.
\end{abstract}

Results: Distribution models accurately predicted caribou at a spatially-explicit, 500-m scale. Model analyses identified migratory areas that shifted annually across the region, but which predicted 4 main areas of repeated use. Niche models were defined largely by non-linear relationships with coastally-influenced, climatic variables, especially snow-free date, potential evapo-transpiration, growing season length, proximity to sea ice, winter precipitation and fall temperature. Proximity to roads and communities were also important and we predicted caribou to generally occur more than 20-100 km from these features.

Conclusions: Western Arctic Herd caribou were predicted to occur in warmer, snow-free and treeless areas that may provide conditions conducive for efficient travel and foraging. Rapidly changing seasonal climates and coastal influences that determine forage availability, and human impediments that slow or divert movements are related to geographically and phenologically dynamic migration patterns that may periodically shift caribou away from traditional harvest areas. An enhanced understanding of the geographic behavior of caribou over time could inform traditional harvests and help conserve important Western Arctic caribou migratory areas.

Keywords: Alaska, Caribou, Climate, Ecological niche model, Infrastructure, Machine learning, Potential evapotranspiration, Rangifer tarandus, Snow, Stochastic gradient boosting

* Correspondence: andy.baltensperger@usd.edu

4175 Geist Rd, National Park Service, Fairbanks, AK 99709, USA

(c) The Author(s). 2019 Open Access This article is distributed under the terms of the Creative Commons Attribution 4.0 International License (http://creativecommons.org/licenses/by/4.0/), which permits unrestricted use, distribution, and reproduction in any medium, provided you give appropriate credit to the original author(s) and the source, provide a link to the Creative Commons license, and indicate if changes were made. The Creative Commons Public Domain Dedication waiver (http://creativecommons.org/publicdomain/zero/1.0/) applies to the data made available in this article, unless otherwise stated. 


\section{Background}

Animals undertake a variety of movements based on both intrinsic and external factors including climate, food availability, competition, and predation risk [1, 2]. Movement decisions are made at a range of scales from individual steps (length and direction) [3, 4] to the selection of patches $[5,6]$, and seasonal migratory route finding through regional landscapes [7]. Long-distance migrations have been identified in a variety of North American ungulates including pronghorn (Antilocapra americana [8], elk (Cervus canadensis [9], mule deer (Odocoileus hemionus) [5, 10, 11], bison (Bison bison) [12], moose (Alces alces) [13] and caribou (Rangifer tarandus) [14]. Migration is often defined as the cyclical movement of populations between disjunct ranges as a means of increasing fitness as populations seek quality forage and avoid seasonally abundant pests and predators $[15,16]$.

The prevalence and length of long-distance terrestrial migrations have been steadily declining and phenology has been altered due to a range of limiting factors. Impediments to movement include barriers such as transportation corridors [16-19], fences [8], urban and industrial development $[20,21]$, unavailable forage and habitat [5], and unstable ice and snow conditions [22-24]. These obstacles cause animals to expend additional time and energy to navigate. Disturbances to seasonal movements of herds may also include wildfires, high densities of hunters, predators, or development near migratory bottlenecks or stopover sites [25-28]. Because migration routes are difficult to restore once interrupted, identifying and conserving important migratory areas now should be a top priority for land managers $[7,18,25]$.

Alaska includes over 30 herds of caribou distributed throughout the state, although many of these are smaller herds that undertake only local migrations or none at all [29]. Four large migratory herds range across the Brooks Range in northern Alaska. The largest among these is the Western Arctic Herd (WAH), comprising 259,000 individuals in 2017 and distributed seasonally across over $360,000 \mathrm{~km}^{2}$ of northwestern Alaska (Fig. 1) [30, 31]. After reaching its historic nadir of 75,000 individuals in 1976, the WAH grew rapidly to nearly 490,000 animals, making it one of the largest caribou herds in the world in 2003 [32]. By 2016, the herd had declined $60 \%$ to 201,000 animals [30]. During their typical annual migratory cycle, WAH caribou travel from wintering grounds on and near the Seward Peninsula, over the Brooks Range to calve on the North Slope. They then make their way towards the coast to escape insect harassment in mid-summer before returning south again in fall to their wintering grounds. The straight-line, round-trip distance between their winter and calving areas exceeds $1000 \mathrm{~km}$, which is among the longest terrestrial migrations on the planet [25]. Caribou wander extensively and their total annual movements exceed $4400 \mathrm{~km}$ [33].

The WAH is one of the most important subsistence resources in northwest Alaska, providing local rural residents from over 40 communities with 11,000 caribou annually [27, 32]. During the 2000s, rural residents began to observe shifts in migrations away from communities, changes in herd phenology, and a decrease in the number and quality of caribou available for harvest [34]. On average, sport hunters comprised roughly $5 \%$ of the total harvest each year until 2016 [27, 32, 35]. These user groups have come into conflict as traditional harvesters have perceived aircraft noise, often associated with sport hunting to be disruptive to caribou movements [36, 37]. However, research has not found influence of hunter activity on herd behavior at caribou movements at broad scales in the Noatak River Valley [27]. In an effort to stem the herd's decline, managers instituted closures for sport hunting and limits on traditional harvest in 2016 [33]. At this time, the herd is showing signs of recovering survival and recruitment rates [30]. The health of the herd and the location of migratory movements from year to year will determine the success of subsistence harvesters who rely on caribou for their own food security.

However, human development has been shown to influence caribou distributions during all seasons $[16,20]$. Transportation and industrial corridors such as frequently-traveled roads and railways as well as pipelines and seismic lines can act as barriers by delaying or interrupting crossing, especially when perpendicular to the direct of travel $[16,38]$. Roads and railways are also direct sources of mortality through collisions $[17,21]$ and increased vigilance around these obstacles may also reduce foraging efficiency, harming individual health. Wilson et al. documented a delay in collared, female WAH caribou by an average of 33 days while crossing the Red Dog Mine road [16]. The distribution of the $\mathrm{CAH}$ during calving in the Prudhoe Bay area has also been shown to be inversely related to road density and to shift at least $5 \mathrm{~km}$ away from pipelines and roads with even limited traffic levels of $100-200$ vehicles/day, although they may use these areas during the insect relief season [20,39]. Other disturbances associated with concentrations of humans that may affect caribou include noise disturbance from water- and aircraft [37], and industrial machinery [40].

In addition to anthropogenic impediments, caribou distribution patterns in northern Alaska are related to a collection of climate-induced effects including increased fire frequency and vegetative biomass, which act to convert lichen tundra to shrub-lands [41], reducing available winter forage [22, 28]. Global climate change is already resulting in stronger and more intense storms and deeper snow-packs [42], but also more frequent rain-on- 


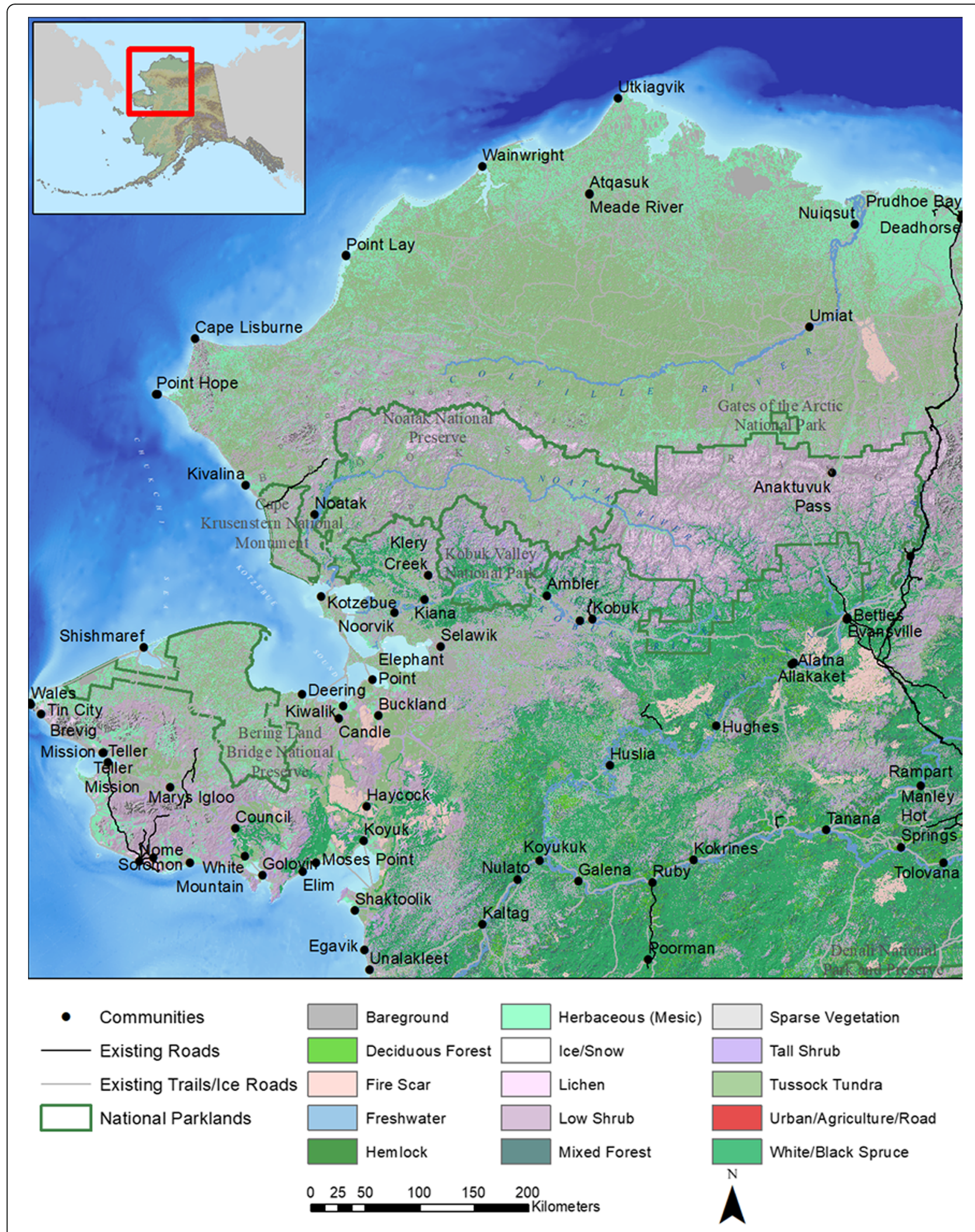

Fig. 1 Study area map. Map of northwestern Alaska including its placement relative to the state of Alaska (inset), geographic landmarks, anthropogenic features, National Park Service boundaries (green), and land cover ecotypes. The extent of the map indicates the study area 
snow events that increase snow-pack density [43, 44]. Such conditions make it difficult for caribou to access lichens and to travel efficiently in winter and spring [45]. The size of the WAH has also been shown to vary with changes in the PDO (Pacific Decadal Oscillation) [45], where positive phases (warmer conditions) tend to correlate with herd growth and larger population sizes versus smaller, declining populations during negative phases (colder conditions) [45]. Furthermore, the dramatic decrease in sea ice extent observed over the past decades has also been hypothesized to affect caribou through changes in weather patterns, especially during the insect-avoidance season [22, 46]. The combined effects of shifting mean temperatures and precipitation, prevailing winds, insect phenology, and plant growth, affect the forage availability, predation rates, calf recruitment, individual body condition and ultimately the population distribution of the WAH throughout the year [45].

Quantifying seasonal ranges, defining migratory habitat and detecting changes in caribou distributions and migration geography over time are among the stated monitoring objectives for the National Park Service [33], and providing up-to-date information to local communities may help them to adapt to a rapidly changing Arctic [34]. Despite regular research to estimate herd size, studies to quantify and track migratory areas in northern $\mathrm{Al}-$ aska have only been conducted for the Central Arctic Herd (CAH) [7]. The factors behind WAH population dynamics, migratory patterns, and overall health are numerous and interactive, so deciphering these drivers and identifying impediments requires a multivariate approach that can incorporate dozens of variables. Here we use the machine learning algorithm, TreeNet, to analyze GPS telemetry data for the WAH over 8 years. This approach uses associations between caribou and the environment to develop accurate predictive models, identify important system predictors, and define nonlinear responses. Our goals were to 1) model caribou seasonal distributions and change, 2) relate caribou occurrence to climatic, anthropogenic, and topographic predictors, and 3) to identify migratory areas predicted to have been used consistently by the WAH over the past decade. We hope these results may help to conserve an important regional subsistence resource and promote the preservation of one of the largest and longest remaining terrestrial migrations in the world.

\section{Methods}

\section{Data collection}

Over the past decade, 211 adult female caribou belonging to the WAH were captured in Kobuk Valley National Park, Alaska and fitted with GPS telemetry collars (Telonics TGW-4680, Mesa, Arizona, USA) following protocols approved by a State of Alaska Institutional Animal Care and Use Committee (IACUC 0040-2017-40) [33]. Only adult ( $>2$ years old) female caribou were fitted with collars, which collected position data every $8 \mathrm{~h}$ throughout the year (1095 relocations per caribou per year).

\section{Model development}

We used the machine learning algorithm, TreeNet (Salford Systems, Inc., San Diego, CA), a type of stochastic gradient boosting, to analyze associations between locational records of caribou and dozens of climatic, topographic, and anthropogenic predictors (Table 1), and to spatially model herd distribution during biologically significant seasons over 8 years. This approach, which uses iterative tree-building to reduce overall error and collinearity among points and predictors, is known as "boosting" and differs from traditional frequentist statistical analyses in its analysis and assumptions. Boosted decision tree analyses are capable of quantifying complex, non-linear relationships among many interacting categorical and continuous predictors, and are insensitive to outliers and missing data [47, 48]. Because TreeNet is a data-driven approach and not specifically designed to test a priori hypotheses, datasets need not conform to assumptions of normality and independence, and so do not require prior data manipulation. We chose this approach over parametric analyses like dynamic Brownian Bridge and step-selection analyses, that are constrained by a priori assumptions, for its ability to incorporate numerous, interacting, non-linear, environmental relationships in predicting the distribution of species across broad landscapes. While this approach is unable to determine causation between predictors and the response, it is adept at producing accurate predictions and useful for exploring the relative importance and non-linear responses of predictors.

We developed landscape distribution models for northwestern Alaska based on GPS locations attributed with 37 environmental predictors for 6 seasons (averaged over the course of 8 years) as well as each year for the spring and fall migratory seasons (Table 1). For consistency, we defined seasons based on previously determined date ranges (Joly and Cameron 2017). We developed distribution models for 6 biologically-relevant seasons: spring (April 1-May 27), calving (May 28-June 14), insect-relief (June15-July 14), late summer (July 15-August 31), fall (September 1-November 30), and winter (December 1March 31). Training datasets for each season consisted of the recorded locations for all individuals across all years for which we had data. Because models are based on presenceonly datasets, we used sets of randomly-distributed pseudoabsences in lieu of observed absences, which are not inherent to telemetry datasets. We determined the numbers of 
Table 1 Predictors and variable importance scores in seasonal distribution models of the Western Arctic Herd

\begin{tabular}{|c|c|c|c|c|c|c|c|}
\hline Included 2010 Predictors (units) & Source & Spring & Calving & Insect Relief & Late Summer & Fall & Winter \\
\hline Active Layer Thickness* $\Delta(m)$ & www.snap.uaf.edu/tools/data-downloads & 31.0 & 15.1 & 16.6 & 15.6 & 31.4 & 18.4 \\
\hline Aspect $\left(^{\circ}\right)$ & ned.usgs.gov & 27.6 & 13.5 & 11.3 & 15.2 & 24.6 & 10.6 \\
\hline Coast Distance (m) & www.asgdc.state.ak.us & 43.3 & 23.6 & 18.3 & 24.0 & 42.9 & 34.8 \\
\hline Elevation (m) & ned.usgs.gov & 30.6 & 13.2 & 14.3 & 15.7 & 32.3 & 16.1 \\
\hline Freeze Date $\triangle$ (Julian date) & www.snap.uaf.edu/tools/data-downloads & 9.7 & 4.2 & 3.1 & 5.3 & 17.9 & 7.3 \\
\hline Thaw Date ${ }^{*}($ (Julian date) & www.snap.uaf.edu/tools/data-downloads & 17.2 & 5.5 & 5.1 & 4.1 & 12.3 & 8.5 \\
\hline Fire History $\Delta$ (year) & agdc.usgs.gov/data/projects/fhm & 14.6 & 3.8 & 2.5 & 3.2 & 14.1 & 15.9 \\
\hline Lake Distance (m) & nhd.usgs.gov & 31.5 & 15.3 & 11.6 & 17.6 & 29.4 & 15.5 \\
\hline Growing Season Length* $\triangle$ (days) & www.snap.uaf.edu/tools/data-downloads & 32.8 & 9.6 & 6.2 & 10.0 & 51.2 & 16.0 \\
\hline Ground Temperature* $\Delta\left({ }^{\circ} \mathrm{C}\right)$ & www.snap.uaf.edu/tools/data-downloads & 36.6 & 14.8 & 11.7 & 15.0 & 64.6 & 21.3 \\
\hline NDVI Greenup Rate $\triangle$ (-0.2--1.0) & nhd.usgs.gov & 25.6 & 13.7 & 11.7 & 16.1 & 24.8 & 10.7 \\
\hline Max NDVI $\triangle(-0.2--1.0)$ & alaska.portal.gina.alaska.edu/search & 22.2 & 5.4 & 7.9 & 17.9 & 27.5 & 15.6 \\
\hline Potential Evapotranspiration* $\triangle(\mathrm{mm} / \mathrm{yr})$ & arcticlcc.org/products/spatial-data & 69.0 & 100.0 & 100.0 & 28.1 & 100.0 & 35.5 \\
\hline Permafrost Probability (\%) & [91] & 18.9 & 10.6 & 10.2 & 16.0 & 32.9 & 18.1 \\
\hline Winter Precipitation* $\triangle(\mathrm{mm})$ & www.snap.uaf.edu/tools/data-downloads & 100.0 & 13.0 & 8.0 & 57.6 & 47.1 & 25.3 \\
\hline Summer Precipitation* $\triangle(\mathrm{mm})$ & www.snap.uaf.edu/tools/data-downloads & 26.7 & 12.7 & 14.2 & 21.4 & 34.0 & 26.9 \\
\hline Spring Precipitation* $\triangle(\mathrm{mm})$ & www.snap.uaf.edu/tools/data-downloads & 31.5 & 25.4 & 6.7 & 15.8 & 27.8 & 19.1 \\
\hline Fall Precipitation* $\triangle(\mathrm{mm})$ & www.snap.uaf.edu/tools/data-downloads & 35.7 & 12.5 & 35.5 & 20.1 & 44.4 & 21.1 \\
\hline Stream Distance $(\mathrm{m})$ & nhd.usgs.gov & 30.1 & 13.9 & 10.8 & 15.8 & 26.8 & 13.9 \\
\hline Road Distance $(\mathrm{m})$ & www.asgdc.state.ak.us & 60.9 & 31.1 & 26.5 & 27.9 & 44.3 & 39.1 \\
\hline Max (Mar) Sea Ice Distance $\triangle(m)$ & [92] & 53.4 & 18.7 & 12.9 & 17.1 & 41.8 & 30.9 \\
\hline Min (Sep.) Sea Ice Distance* $\triangle(m)$ & [92] & 58.3 & 47.5 & 16.4 & 21.9 & 43.2 & 37.4 \\
\hline Slope ( ) & ned.usgs.gov & 28.4 & 13.3 & 12.2 & 17.9 & 34.8 & 13.0 \\
\hline Winter Snow Day Fraction* $\triangle(\%)$ & www.snap.uaf.edu/tools/data-downloads & 11.6 & 2.8 & 14.1 & 24.7 & 20.6 & 100.0 \\
\hline Summer Snow Day Fraction* $\triangle(\%)$ & www.snap.uaf.edu/tools/data-downloads & 18.1 & 10.0 & 6.1 & 9.3 & 14.8 & 10.0 \\
\hline Spring Snow Day Fraction* $\triangle(\%)$ & www.snap.uaf.edu/tools/data-downloads & 25.2 & 7.2 & 7.0 & 9.0 & 16.1 & 13.6 \\
\hline Fall Snow Day Fraction* $\triangle(\%)$ & www.snap.uaf.edu/tools/data-downloads & 26.6 & 7.0 & 6.9 & 100.0 & 23.7 & 19.9 \\
\hline Snow-free Date ${ }^{*} \triangle$ (Julian date) & [62] & 64.2 & 10.4 & 9.3 & 11.7 & 27.7 & 25.8 \\
\hline Winter Temperature ${ }^{*}\left({ }^{\circ} \mathrm{C}\right)$ & www.snap.uaf.edu/tools/data-downloads & 25.8 & 17.4 & 9.0 & 15.6 & 29.5 & 28.1 \\
\hline Summer Temperature ${ }^{*} \Delta\left({ }^{\circ} \mathrm{C}\right)$ & www.snap.uaf.edu/tools/data-downloads & 28.3 & 15.4 & 7.6 & 10.2 & 28.5 & 12.0 \\
\hline Spring Temperature ${ }^{*} \triangle\left({ }^{\circ} \mathrm{C}\right)$ & www.snap.uaf.edu/tools/data-downloads & 22.0 & 12.1 & 9.8 & 10.5 & 24.7 & 12.6 \\
\hline Fall Temperature ${ }^{*} \Delta\left({ }^{\circ} \mathrm{C}\right)$ & www.snap.uaf.edu/tools/data-downloads & 65.4 & 20.8 & 9.3 & 13.7 & 26.6 & 21.4 \\
\hline Distance to Trails (m) & www.asgdc.state.ak.us & 35.7 & 16.1 & 17.0 & 18.9 & 34.2 & 23.6 \\
\hline Terrain Ruggedness $17 \times 17(0-1)$ & ned.usgs.gov & 28.2 & 20.6 & 18.7 & 21.4 & 28.8 & 33.7 \\
\hline Terrain Ruggedness $3 \times 3(0-1)$ & ned.usgs.gov & 26.5 & 13.8 & 12.1 & 16.1 & 24.4 & 10.5 \\
\hline Community Distance (m) & www.asgdc.state.ak.us & 43.4 & 14.9 & 11.9 & 15.1 & 43.6 & 13.6 \\
\hline Wetland Distance $(\mathrm{m})$ & https:/www.fws.gov/wetlands/Data/Data-Download.html & 25.4 & 13.7 & 11.9 & 15.6 & 30.7 & 13.8 \\
\hline
\end{tabular}

Predictors denoted with an * are decadal means, and $\Delta$ indicates dynamic predictors that change annually. Active layer thickness is the depth of ground that thaws and freezes each year. Freeze and thaw dates refer to the mean annual date of first freeze (or thaw) during 2010-2020. Fire history denotes the year of the most recent fire in a given area. Growing season length is defined as the number of days between the date of first thaw and date of first freeze. Ground temperature refers to the modeled mean annual ground temperature. NDVI (Normalized Difference Vegetation Index) is an infrared-based measure of landscape greenness indicative of biomass; green-up rate and maximum NDVI are annual metrics calculated from NDVI. Potential evapotranspiration (PET) here is the amount of evaporation that would occur over a year if a sufficient water source were available. Seasonal climate variables are decadal averages of downscaled seasonal totals. Seasons are grouped as follows: Spring (Mar.-May), Summer (Jun.-Aug.), Fall (Sep.-Nov.), Winter (Dec.-Feb.). Permafrost probability describes the distribution of near-surface permafrost. Distance refers to the shortest Euclidean distance to the nearest feature. Snow day fraction is an average of the percentage of days with snow on the ground. Terrain ruggedness predictors were calculated from slope and elevation using 2 moving window scales of 3 and 17 $\mathrm{m}$, respectively. Predictor importance values are out of 100.0 with the top predictor always receiving the maximum 
pseudo-absences in each model by multiplying the number of presences for each season or year by the study area extent and dividing by the minimum convex hull area of the presence locations. We did this to ensure that the relative densities of presences and pseudo-absences were consistent across seasons and years to avoid 'swamping' the presence set. We defined the study area as the portion of northwest Alaska encompassing the full extent of telemetry locations from 2010 to 2017 (e.g., Fig. 1).

Together presences and pseudo-absences composed the training dataset for each model. We attributed these points with the 37 environmental predictors using the 'extract' function in R 3.5.1 (R Development Core Team 2018). Environmental predictors in the models included climatic, anthropogenic, geographic and topographic predictors known or hypothesized to affect caribou ecology in some way (Table 1). We then analyzed the training data, using TreeNet, to iteratively classify non-linear relationships between predictors and the response (Relative Index of Occurrence; RIO). We used model classifications to make predictions regarding the spatiotemporal distributions of caribou, to identify important predictors in the models, and to quantify thresholds of influence in the non-linear contribution of those predictors to the response. TreeNet functions by first developing a single decision tree to estimate the main effect on the response by accounting for the largest proportion of variance in a system $[47,49]$. In subsequent, iterative steps, additional trees are 'grown' to explain the residual error that remains from previous trees $[48,49]$. TreeNet builds thousands of trees, uses recursive data sampling, and predictors enter the model in a gradual, non-linear fashion, with different splitting rules each time they are used. This iterative resampling helps to minimize the effect of issues such as model over-fitting [47, 48] and spatial autocorrelation [50, 51]. Stochastic gradient boosting algorithms also automatically include interactions among all predictors in a model [48, 49, 52, 53]. Boosting improves model accuracy by averaging contribution from numerous satisfactory but imperfect models in a successive fashion rather than attempting to find a single parsimonious model to approximate the system $[48,49,53,54]$.

We varied the number of trees (1000-2000), number of nodes per tree (6-20), and minimum cases per terminal node (2-50) in TreeNet to identify the best model with the highest area under the receiver operators curve (AUC) and the lowest misclassification rate. We excluded the poorest performing predictors in successive modeling attempts to improve predictive accuracy, but the full predictor set proved to be most accurate. We used the 'balanced' option to ensure equal contribution to the model from unequal class sizes in the response variable. We validated models using two internal means, using the out-of-bag data withheld during the tree building process, and also by withholding $20 \%$ of the training data (test subset) before model construction. Models were graded as "excellent" $(1.0>\%$ Correct $>0.90)$, "good" $(0.90>\%$ Correct $>0.80)$, "fair" $(0.80>\%$ Correct $>0.70$ ). We also used telemetry data from 2018 as an independent dataset to validate the predictive spatial accuracy of models by calculating the mean and standard deviation of residuals ( 1 - RIO).

For each model, TreeNet developed a unique algorithm to describe patterns in the data, which was then 'scored' to a regularly-spaced grid of points (500-m resolution) across the study area that was also attributed with the same environmental variables. Predictions at points were smoothed using the inverse-distance weighting function to produce a continuous raster depicting the RIO for caribou in northwestern Alaska. This process was repeated to produce distribution models for each of the 6 caribou seasons pooled across years and 8 individual fall and spring models for each year between 2010 and 2017. TreeNet also produced partial dependence plots for each predictor. These are model-based simulations that chart the non-linear relationship of the response over the range of each predictor variable while controlling for the other variables [55]. Partial dependence plots are useful for depicting trends and identifying threshold levels in predictors which correspond with the predicted presence or absence of caribou. We used partial dependence plots to identify thresholds and delineate data ranges in environmental predictors that were associated with the predicted occurrence of caribou. Each of these ranges represents a single plane of realized niche space composing a theoretical n-dimensional hypervolume of available environmental conditions that constrain the potential niche of caribou [56].

\section{Analyses}

To predict the most common migratory areas, we converted the annual distribution models for the fall and spring seasons to binary models using the 'reclassify' tool in ArcGIS 10.5. Predicted presences were differentiated from predicted absences using the threshold between 0 and 1 that minimized the total error rate for each model [57]. We calculated the total area of predicted presence for each year by multiplying the number of presence pixels by the pixel area $\left(500 \mathrm{~m}^{2}\right)$. We also calculated the mean latitude and mean longitude of observed telemetry locations in spring and fall to quantify geographic shifts among years. For both migratory seasons, we summed models across years to determine the number of years each pixel was predicted to have been used by caribou. From these, we identified primary migratory areas that were predicted to have been used repeatedly by caribou across the study area in both spring and fall. We also 
used ArcGIS to calculate the mean pixel values of the top environmental predictors in areas of predicted presence and absence in spring and fall. We intentionally excluded a spatial land cover predictor from the model to subsequently evaluate proportional land cover use independently in relation to predicted distribution areas. We related predicted presence areas during migratory seasons with a comprehensive land cover map of the region [58] using the tabulate area tool in ArcGIS. We calculated landcover selection by dividing the percentage of pixels predicted as presences in each cover type by the percentage of pixels of that cover type available in the study area.

\section{Results}

\section{Pooled seasonal models}

GPS collars recorded locations of WAH caribou from September 7, 2010 to November 30, 2017 resulting in a total of 465,807 occurrence records. Seasonal models, pooled across years, predicted regions of use by the WAH during the spring, calving, insect-relief, late summer, fall, and winter seasons. Based on AUC scores and overall percent correct, model accuracies ranged from 'good' to 'excellent' in their predictions of the spatiotemporal distribution of caribou in the WAH. Environmental predictors were ranked to show the most influential predictors in the model (Table 1) and partial dependence plots Figures 2, 3, Additional file 1) indicated ranges of each predictor that were associated and disassociated with the predicted distribution of caribou in the models (Fig. 4).

The spring model predicted the presence of caribou in a belt of land around the coast of Kotzebue Sound and a band extending northward across the Kobuk River between the communities of Noorvik and Kobuk (Fig. 4a). Three swaths of predicted presence diffused north over the Baird Mountains and across the breadth of Noatak National Preserve (NOAT). Areas of high RIO extended over the Brooks Range across numerous mountain passes before converging on the North Slope. The overall accuracy for the best pooled spring model was deemed 'good' $(\mathrm{AUC}=0.95$; Overall Accuracy test $=$ 88.45\%; Mean Residual $2018=0.39 \pm 0.30$ ) at a presence/ absence threshold of 0.61 . Winter precipitation was the most important predictor in the spring distribution model (Table 1), which predicted caribou to occur in areas with more than $70 \mathrm{~mm}$ of winter precipitation (Fig. 2a). The mean precipitation in areas predicted as presences was $84.8 \mathrm{~mm}$ versus $66.8 \mathrm{~mm}$ in absence areas. PET (potential evapo-transpiration) was also highly predictive of the presence of caribou (Table 1), especially in areas where the mean evaporative potential was 220 $350 \mathrm{~mm}$, but the 2 were negatively correlated when PET exceeded $350 \mathrm{~mm}$ (Fig. 2b). The mean evaporative potential in predicted presence areas was $293.0 \mathrm{~mm}$ versus $360.0 \mathrm{~mm}$ across absence areas. Models also generally predicted caribou to occur in areas where mean decadal fall temperatures were above $-4^{\circ} \mathrm{C}$ (Fig. 2c) and where average snow melt occurred between April 20 and May 10 (Fig. 2d). Local snow melt timing varied by as much as 2 months across ridgelines in areas frequented by caribou. The model showed a tendency for caribou to be negatively associated with roads at distances within $40 \mathrm{~km}$ (mean $=89.7 \mathrm{~km}$; Fig. $2 \mathrm{e})$, and positively correlated when between 40 and $200 \mathrm{~km}$ from roads (mean $=128.8 \mathrm{~km}$ ). Caribou were also predicted to occur within $100 \mathrm{~km}$ of the

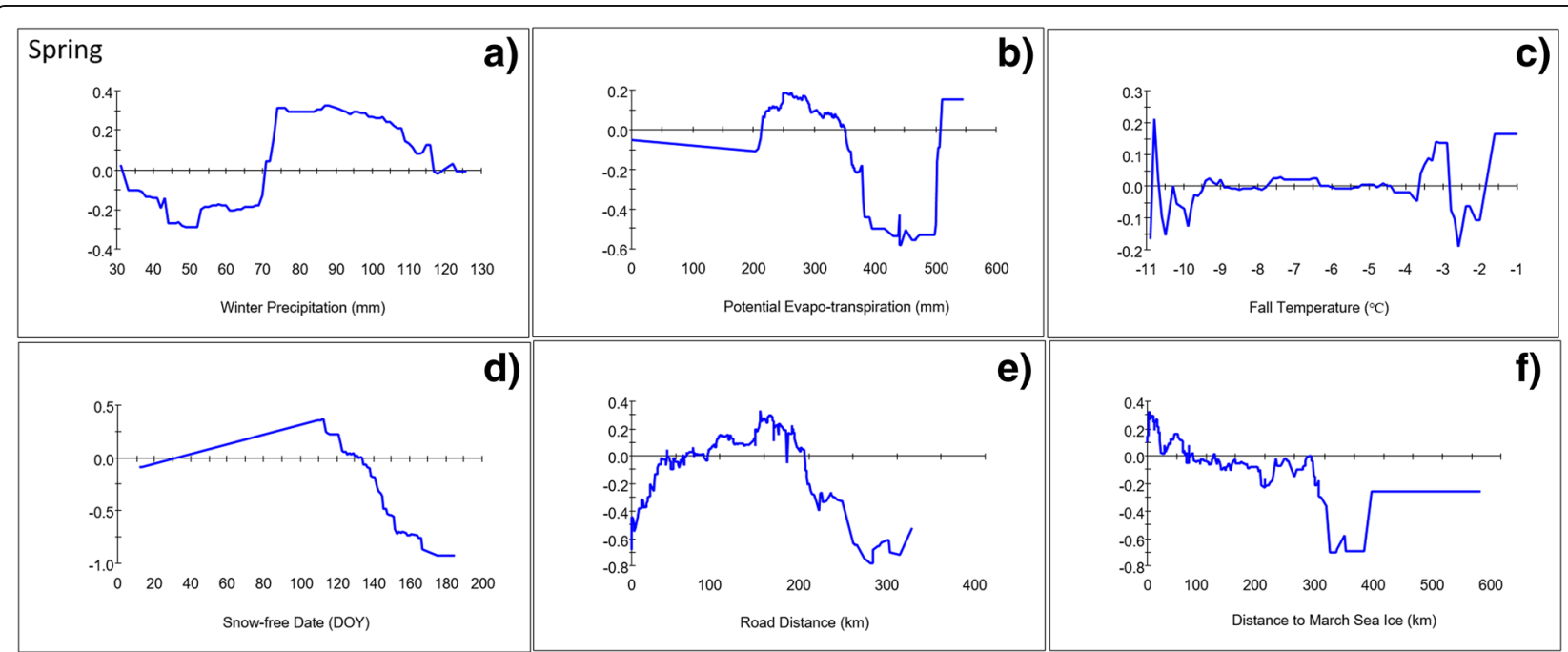

Fig. 2 Partial-dependence plots for the top 6 predictors, mean winter precipitation (a), potential evapotranspiration (b), mean fall temperature (c), mean snow-free date (d), distance to nearest road (e), and distance to mean maximum sea ice extent (f), for the pooled (2010-2017) spring caribou distribution model 


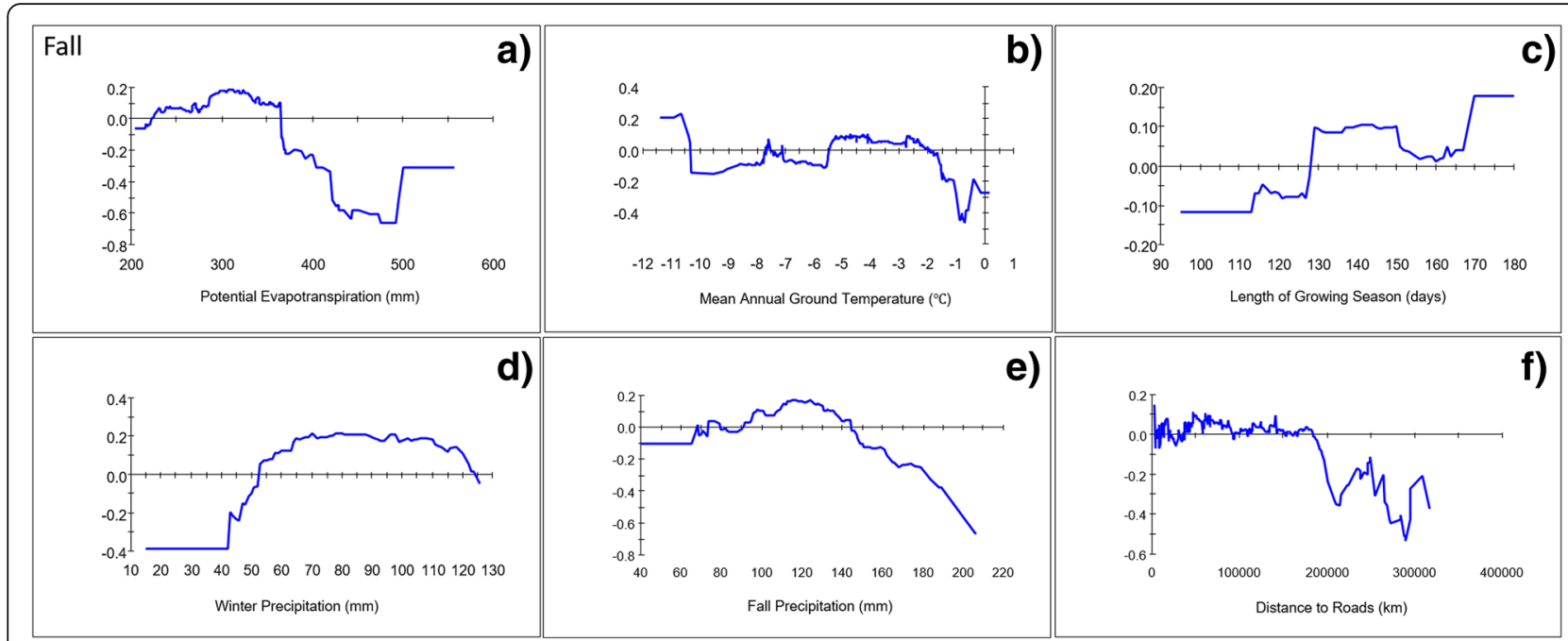

Fig. 3 Partial-dependence plots for the top 6 predictors, potential evapotranspiration (a), mean annual ground temperature (b), mean length of growing season $(\mathbf{c})$, mean winter precipitation (d), mean fall precipitation (e), and distance to nearest road (f), for the pooled (2010-2017) fall caribou distribution model

mean spring sea ice extent (Fig. 2f). Distance to community was ranked as the 8th-most important predictor (Table 1) and the model predicted caribou to occur beyond $\sim 20 \mathrm{~km}$ from the nearest community (Additional file 1: Figure S1). Mean distance to community was 77.7 $\mathrm{km}$ for predicted presences as compared to $58.9 \mathrm{~km}$ for predicted absences.
Spatial projections predicted the majority of animals during the calving season to be concentrated in $\sim 25$, $000 \mathrm{~km}^{2}$ of land surrounding the upper Colville River (Fig. 4b). Areas of high RIO trailed to the south as far as western Kotzebue Sound but in decreasing breadth and intensity. The calving model accuracy was deemed 'excellent' (AUC $=0.98$; Overall Accuracy $y_{\text {test }}=93.53 \%$,

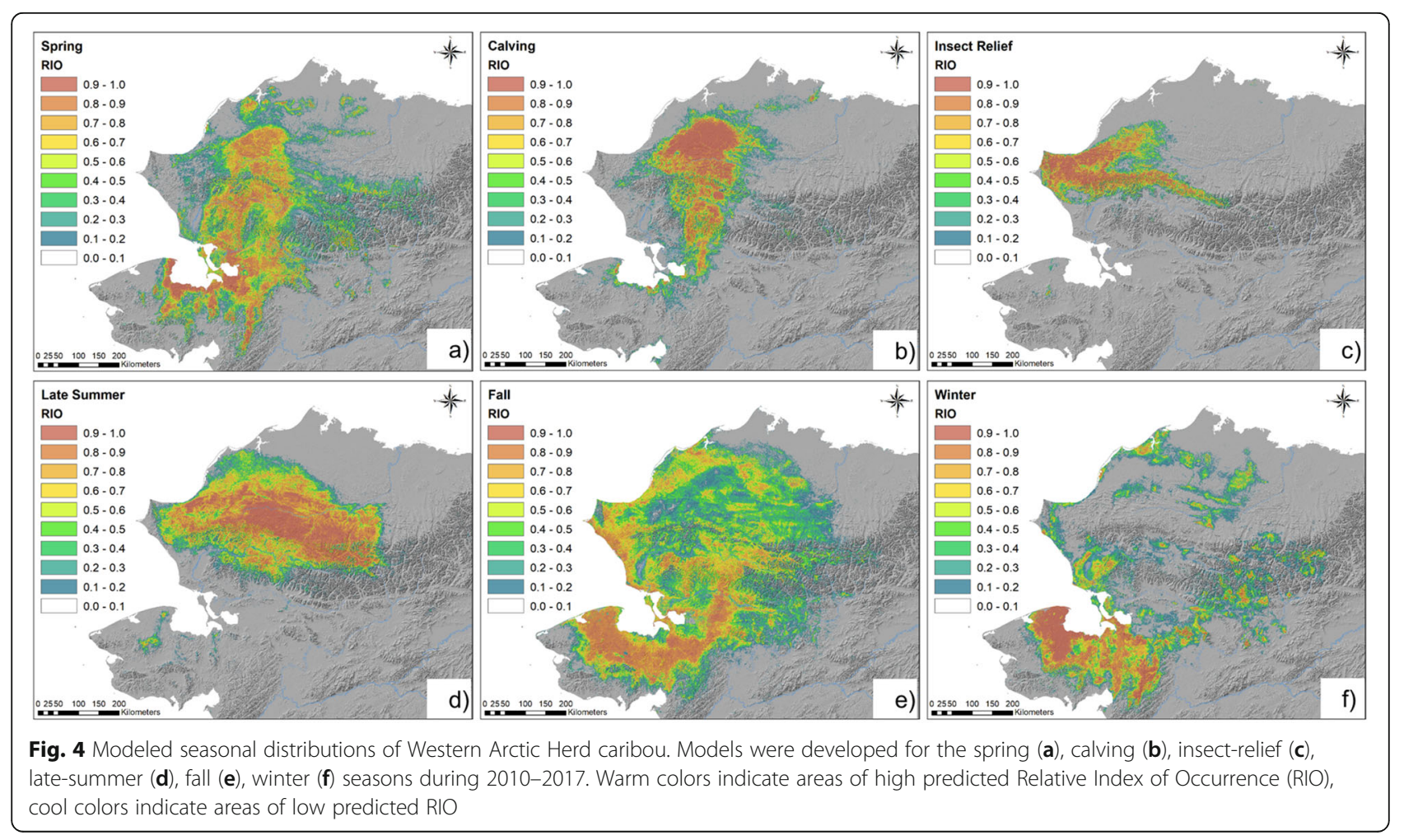


Mean Residual $2018=0.05 \pm 0.06$ ) using a balanced presence/ absence threshold of 0.62 . During the calving season, the presence of caribou was most-closely associated with PET (Table 1), especially in areas where PET was less than 260 $\mathrm{mm}$ (Additional file 1: Figure S2). Caribou were predicted to occur at distances of $470-600 \mathrm{~km}$ from the mean September sea ice extent (Additional file 1: Figure S2). Distance to roads was also influential in the calving model (Table 1) with caribou tending to occur in areas $100-250 \mathrm{~km}$ from roads (Additional file 1: Figure S2). Distance to communities was ranked 7th in relative importance (Table 1) and the model predicted caribou to be negatively associated with communities at distances less than $80 \mathrm{~km}$ (Additional file 1).

During the insect relief season, models predicted nearly all caribou to occur north of the Noatak River, with most concentrated in an area near the coast but east of Point Hope (Fig. 4c). Two 'tails' extended on either side of the Colville River; 1 running along the north side of the DeLong Mountains as far east as Gates of the Arctic National Park and Preserve (GAAR), and the other farther onto the North Slope. Model accuracy for the insect-season model was 'excellent' $(\mathrm{AUC}=0.98$; Overall Accuracy test $=93.84 \%$, Mean Residual ${ }_{2018}=0.09$ $\pm 0.06)$ at a balanced threshold of 0.75 . The most important predictor of high RIO values in the model was PET (Table 1), which was directly correlated with caribou in areas with an average evaporative potential of < $225 \mathrm{~mm}$ (Additional file 1: Figure S3). Precipitation was also important (Table 1) and directly related to high RIO in areas receiving an average of $>85 \mathrm{~mm}$ in fall (Additional file 1: Figure S3). There was also a disassociation between human infrastructure and caribou during the insect season, where caribou were not generally predicted to occur within $20 \mathrm{~km}$ of roads or within $53 \mathrm{~km}$ of communities (Fig. 2e, Additional file 1: Figure S3). Distance to the coast also influenced the model (Table 1) and indicated a roughly inverse linear relationship between caribou and the coast, with caribou predicted to occur in areas more than $70 \mathrm{~km}$ from the Bering Sea (Additional file 1: Figure S3).

During the late-summer season, the model predicted caribou over a broad area extending from the DeLong Mountains to north of the Colville River (Fig. 4d). Longitudinally, the area reached from east of Point Hope nearly to the community of Anaktuvuk Pass in the central Brooks Range. Other areas predicted as presences included much of NOAT and the northwestern portion of GAAR. The best model for the late summer season $(\mathrm{AUC}=0.97$; Overall Accuracy test $=87.02 \%$, Mean Residual $_{2018}=0.11 \pm .06$ ) had 'good' accuracy using a balanced threshold of 0.75 . The most important environmental variable in the late-summer model was fall snowday fraction (Table 1) with caribou tending to occur in areas where snow occurred on the ground more than $70 \%$ of days in fall (Additional file 1: Figure S4). Winter precipitation was also influential in predicting caribou and was positively related to presences in areas averaging more than $55 \mathrm{~mm}$ in winter (Additional file 1: Figure S4). PET was somewhat less predictive in this model but was correlated with caribou presence in areas where average annual PET was $200 \mathrm{~mm}-300 \mathrm{~mm}$ (Additional file 1: Figure S4). Caribou were also predicted to occur in areas at least $40 \mathrm{~km}$ from roads (Additional file 1: Figure S4). Winter snow day fraction was somewhat important (Table 1) and corresponded with the presence of caribou where snow was typically on the ground more than $90 \%$ of winter (Additional file 1: Figure S4). Distance to communities ranked 7th in relative importance (Table 1) and was positively correlated with predicted caribou occurrence from 12 to $144 \mathrm{~km}$ away (Additional file 1: Figure S4).

The spatial distribution of the fall model shows wide geographic variation across predicted presence areas (Fig. 4e). The core distribution during this period was predicted to occur from near the community of Kobuk in the north, to the south and west around the margins of Kotzebue Sound, to Bering Land Bridge National Preserve (BELA). Other areas with high RIO included a swath along the western boundary of Kobuk Valley National Park (KOVA) to Kiana and to the east of Kotzebue Sound, a second band ran along the coast from Wainwright to Kotzebue, while other predicted presence areas were scattered across the eastern half of NOAT and the North Slope (Fig. 3e). The pooled fall model predicted the presence of caribou with 'good' accuracy $($ AUC $=0.91$; Overall Accuracy test $=83.44 \%$; Mean Residual $_{2018}=0.30 \pm 0.13$ ) using a balanced threshold of 0.47. A combination of numerous predictors contributed to the model, but several climatic factors were most important (Table 1). The top variable, PET, was predictive of caribou in areas where average annual evaporative potential was $225-365 \mathrm{~mm}$ (Fig. 3a). The mean evaporative potential in presence areas was $294.5 \mathrm{~mm}$ versus 368.9 $\mathrm{mm}$ in absence areas. The occurrence of caribou was also strongly associated in areas where mean annual ground temperatures were between $-2{ }^{\circ} \mathrm{C}$ and $-5.5^{\circ} \mathrm{C}$ (Fig. 3b). Growing season length was also highly predictive of caribou in fall in areas with between 130 and 150 days (Fig. 3c). Fall and winter precipitation were both influential in the model, with caribou predicted to occur in areas with between 90 and $145 \mathrm{~mm}$ of precipitation in fall and between 44 and 125 in winter (Fig. 3d-e). Roads were ranked 6th (Table 1) and at distances less than 180 $\mathrm{km}$ away, there was no clear association with predicted caribou presence and roads in fall (Fig. 3f). The mean distance to roads in predicted presence areas was 116.6 $\mathrm{km}$ as compared to $88.0 \mathrm{~km}$ in absence areas. Distance 
to communities was somewhat positively associated with caribou at distances less than $75 \mathrm{~km}$ (Table 1, Additional file 1: Figure S5) and the mean distance from communities was $63.2 \mathrm{~km}$ for predicted presences versus $60.4 \mathrm{~km}$ for predicted absences. The geographic niche of WAH caribou in fall was also weakly associated with minimum September sea ice $450-660 \mathrm{~km}$ away (Additional file 1: Figure S5).

In winter, models indicated that the highest predicted RIO were concentrated in BELA and eastward across the Seward Peninsula (Fig. 4f). However, sporadic clusters of predicted presences also occurred throughout GAAR, NOAT, Cape Krusenstern National Monument (CAKR) and across the western North Slope. The winter model predicted presences with 'excellent' accuracy $($ AUC $=0.97 ; \quad$ Overall Accuracy test $=92.40 \%$; Mean Residual $_{2018}=0.12 \pm 0.09$ ) using a balanced threshold of 0.65. Winter snow-day fraction was the dominant environmental predictor in the model (Table 1) and was negatively associated with the presence of caribou in areas where snow was typically on the ground more than 99\% of days in winter (Additional file 1: Figure S6). Other predictors including distance to roads, distance to mean minimum sea ice, PET also contributed to the model's prediction of caribou (Table 1). Predicted RIO was higher when caribou were between 130 and $215 \mathrm{~km}$ from the coast (Additional file 1: Figure S6), whereas caribou were not generally predicted to occur within 38 $\mathrm{km}$ of roads (Additional file 1: Figure S6). Distance to community was ranked 6 th in importance (Table 1 ) by the model which predicted caribou to occur at distances between 45 and $108 \mathrm{~km}$ from communities, but the 2 were negatively associated outside of this range (Additional file 1: Figure S6).

\section{Annual migratory models}

Annual models during migration seasons provided the means to identify areas of repeated use representing favored migratory habitat. The size of predicted distributions varied annually in size between $21,641 \mathrm{~km}^{2}$ and 74,071 km $\mathrm{km}^{2}$ between 2009 and 2017 (Table 2). Annual predictions of migration patterns varied geographically over the study period with the predicted core of the WAH shifting longitudinally from year to year. We documented an easterly trend in predicted distribution prior to 2012 that became westerly in subsequent years (Figs. 5, 6, 7). Spring models ranged from between $235 \mathrm{~km}$ to the east and $148 \mathrm{~km}$ to the west of the mean longitude and between $199 \mathrm{~km}$ to the east and $246 \mathrm{~km}$ to the west of the fall model mean (Table 2, Fig. 7). The average latitude varied somewhat between $97 \mathrm{~km}$ south and $58 \mathrm{~km}$ north of the pooled spring model mean and between $75 \mathrm{~km}$ south and $112 \mathrm{~km}$ north of the pooled fall model mean (Table 2).

We summed the annual binary model predictions to identify 4 frequently used habitats (Fig. 8). Areas consistently predicted as presences during both seasons in 5-7 of the 8 years included the area along the western extent of the Baird Mountains (Area 2), the uplands along the western boundary of KOVA near Kiana (Area 3), and along the eastern boundary of KOVA west of Ambler (Area 4). Area 1 which traverses the CAKR coastline past Kotzebue was mainly used in fall, and Area 2 which crosses the Kobuk River north of Noorvik was used primarily in spring. Each year at least 1 alternative migratory area was used in addition to the primary one, however south of the Kobuk River, predicted presences in each year converged on a single main area arcing around Kotzebue Sound and west into BELA. Through this area, models predicted caribou farther inland during the fall than in the spring (Figs. 4, 5, 6). Notably, models did not predict caribou to occur in the lower Noatak valley in most years during either fall or spring.

\section{Land cover use}

The specific land cover types selected by caribou in the fall and spring models varied slightly from year to year depending on the primary migration geography (Fig. 1, Table 3). However, the ranking of mean spring (20102017) selected land cover types closely matched the rankings for the pooled spring model (Table 3). In spring, caribou selected $(>1.00)$ for tussock tundra, tall shrub, and herbaceous (mesic) land cover types, in that order. Use of dwarf shrubs was predicted to occur in proportion to its availability (1.00), whereas lichen was used less than expected based on its availability (0.810.85 ). Rankings of land cover selection were the same as for the pooled spring model and the mean of the annual spring models. Similarly, caribou in the pooled fall model selected tussock tundra, tall shrub, and fire scar cover types (Table 3). Mean land cover use in the annual fall models was the same as the order of the pooled fall model, although they differed in that herbaceous cover types were predicted to be used less than expected $(0.42-$ 0.48 ). Low selection indices for urban areas, ice/snow, mixed forest, and spruce forest in both the spring and fall pooled models reflect the lack of predicted use of this land cover type by caribou during migration (Table 3 ).

\section{Discussion}

We developed ecological niche models that accurately predicted the relative occurrence of WAH caribou over 8 years based on relationships with 37 environmental predictors. We used these models to make inference to the geographic fidelity of caribou migrations, to identify 
Table 2 Geographic areas and observed latitude and longitude for annual and pooled (2009-2017) distribution models for Western Arctic Herd caribou

\begin{tabular}{|c|c|c|c|c|c|c|c|}
\hline Model & $\begin{array}{l}\text { Predicted } \\
\text { Area }\left(\mathrm{km}^{2}\right)\end{array}$ & $\begin{array}{l}\text { Mean Observed } \\
\left.\text { Longitude ( }{ }^{\circ} \mathrm{W}\right)\end{array}$ & SD & $\begin{array}{l}\text { Deviation } \\
\text { from Mean (km) }\end{array}$ & $\begin{array}{l}\text { Mean Observed } \\
\text { Latitude }\left({ }^{\circ} \mathrm{N}\right)\end{array}$ & SD & $\begin{array}{l}\text { Deviation } \\
\text { from Mean }(\mathrm{km})\end{array}$ \\
\hline Spring 2010 & 34,327 & 159.39317 & 1.9 & $88.0 \mathrm{E}$ & 66.38077 & 1.0 & $75.0 \mathrm{~S}$ \\
\hline Spring 2011 & 37,240 & 158.07553 & 2.3 & $234.9 \mathrm{E}$ & 66.67267 & 1.0 & $42.4 \mathrm{~S}$ \\
\hline Spring 2012 & 42,357 & 159.25842 & 4.2 & 103.0 E & 66.41471 & 1.2 & $71.2 \mathrm{~S}$ \\
\hline Spring 2013 & 21,641 & 160.76047 & 1.5 & $64.5 \mathrm{~W}$ & 66.38118 & 0.9 & $74.9 \mathrm{~S}$ \\
\hline Spring 2014 & 38,725 & 160.43486 & 2.2 & $28.1 \mathrm{~W}$ & 67.19233 & 1.2 & $15.5 \mathrm{~N}$ \\
\hline Spring 2015 & 38,914 & 161.29370 & 2.2 & $123.9 \mathrm{~W}$ & 66.93916 & 1.2 & $12.7 \mathrm{~S}$ \\
\hline Spring 2016 & 41,583 & 161.50840 & 1.8 & $147.8 \mathrm{~W}$ & 67.55609 & 1.5 & $56.1 \mathrm{~N}$ \\
\hline Spring 2017 & 47,198 & 159.58935 & 2.7 & $66.1 \mathrm{E}$ & 67.74343 & 1.4 & $77.0 \mathrm{~N}$ \\
\hline Spring (2010-2017) & 61,095 & 160.18242 & 2.6 & - & 67.05322 & 1.3 & - \\
\hline Fall 2010 & 55,941 & 158.39526 & 2.3 & $199.3 \mathrm{E}$ & 67.04180 & 1.1 & $13.0 \mathrm{~N}$ \\
\hline Fall 2011 & 74,071 & 160.00940 & 3.9 & $75.4 \mathrm{E}$ & 67.13202 & 1.4 & $23.1 \mathrm{~N}$ \\
\hline Fall 2012 & 56,131 & 160.22082 & 2.4 & $51.8 \mathrm{E}$ & 66.98286 & 1.6 & $6.4 \mathrm{~N}$ \\
\hline Fall 2013 & 56,684 & 160.56695 & 2.8 & $13.2 \mathrm{E}$ & 66.59784 & 1.2 & $36.5 \mathrm{~S}$ \\
\hline Fall 2014 & 49,026 & 161.57044 & 3.1 & $98.7 \mathrm{~W}$ & 66.57247 & 1.2 & $39.3 \mathrm{~S}$ \\
\hline Fall 2015 & 45,176 & 162.89438 & 2.6 & $246.3 \mathrm{~W}$ & 66.48665 & 1.3 & $48.9 S$ \\
\hline Fall 2016 & 61,165 & 161.02317 & 3.0 & $37.6 \mathrm{~W}$ & 67.12672 & 1.4 & $22.5 \mathrm{~N}$ \\
\hline Fall 2017 & 66,510 & 159.65528 & 3.7 & $114.9 \mathrm{E}$ & 67.92607 & 1.1 & $111.6 \mathrm{~N}$ \\
\hline Fall (2010-2017) & 118,415 & 160.68562 & 3.2 & - & 66.92524 & 1.4 & - \\
\hline
\end{tabular}

Deviations from the mean (and standard deviation) were calculated from observed telemetry locations of caribou and are the difference between each annual model's mean latitude and longitude and the mean latitude and longitude of presences predicted in the pooled model

non-linear thresholds in the environmental conditions most associated with predicted caribou distributions, and to rank their use of specific land cover types during migration. TreeNet's recursive decision tree analysis allowed us to parse and predict this complex and interactive system. Important predictors in most models were primarily associated with 1) climate, 2) coastal features, and 3) human infrastructure. Our analysis also provides detailed and spatially-precise predictions of the migratory tendencies of WAH caribou and what environmental conditions are associated with movement patterns.

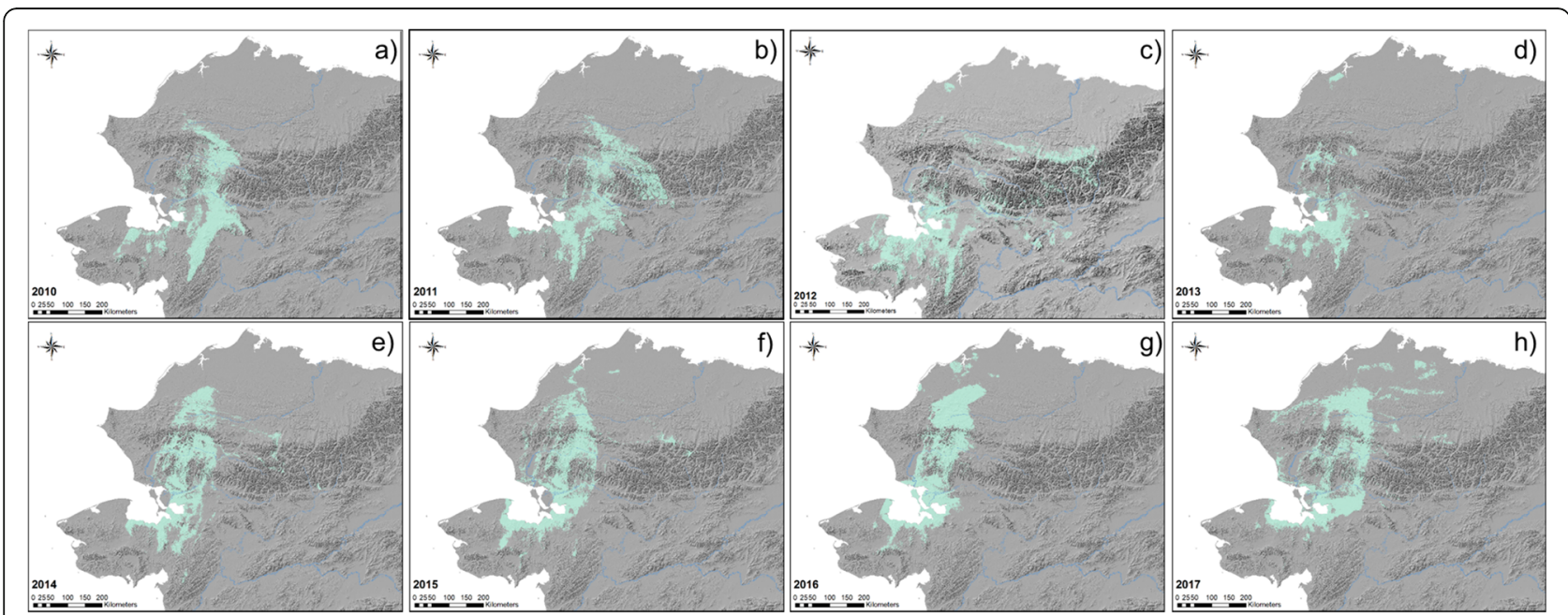

Fig. 5 Modeled distributions of Western Arctic Herd caribou during the spring migration season. Models were developed for each year from 2010 to 2017 (a-h). Shaded area denotes areas of predicted presence based on respective balanced presence/absence thresholds that maximized both sensitivity and specificity 


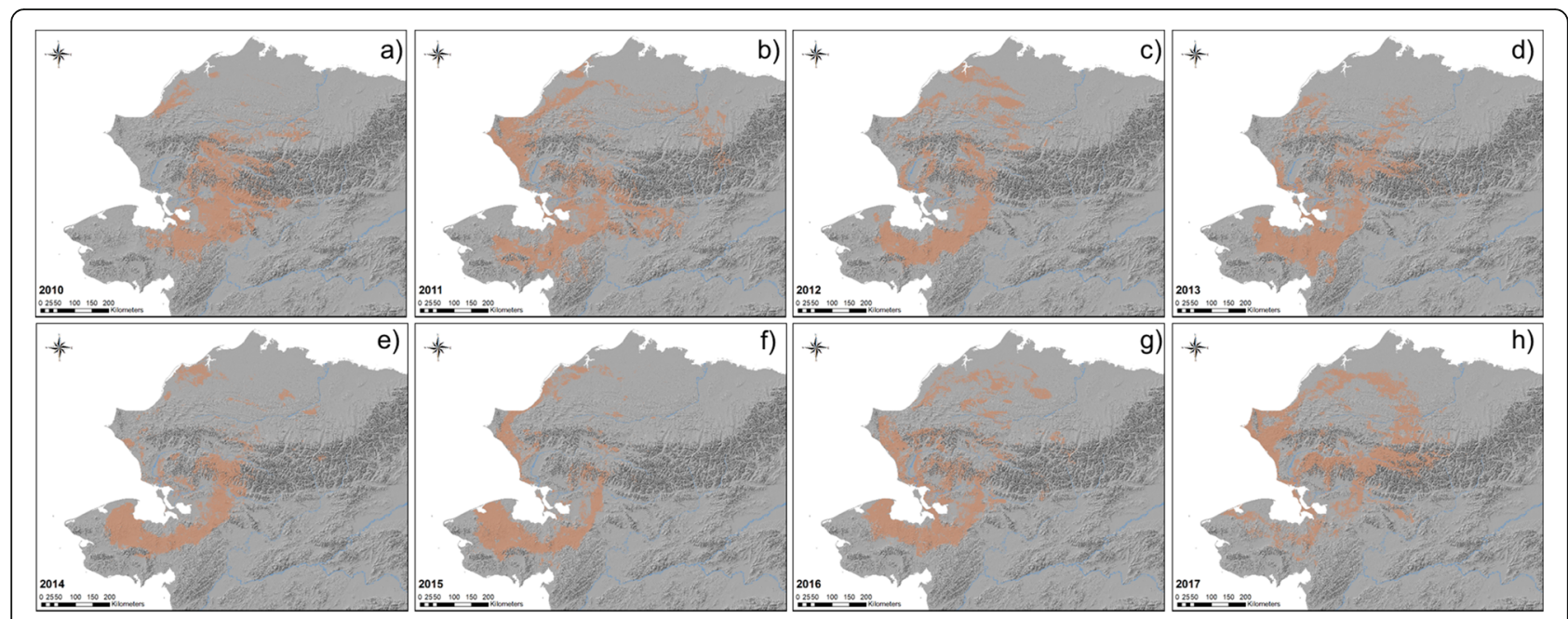

Fig. 6 Modeled distribution of Western Arctic Herd caribou during the fall migration season. Models were developed for each year from 2010 to $2017(\mathbf{a}-\mathbf{f})$. Shaded area denotes areas of predicted presence based on respective balanced presence/absence thresholds that maximized both sensitivity and specificity

\section{Migratory areas}

For the first time, we were able to quantitatively predict the repeated use of the major WAH migratory areas during spring and fall at a $500 \mathrm{~m}$ scale. The 4 main areas used during spring and fall were along both the western and eastern boundaries of KOVA, the western edge of the Baird Mountains, north of Noorvik, and along the west coast through CAKR. These areas were used with varied intensity and frequency, but all were used at least 5 of the 8 years of the study period. Seasonal distribution models developed here provide the highest resolution predictions of spatio-temporal patterns and variation of the WAH, while remaining consistent with other prior distribution estimates (see [33]).
Cross-validated model accuracy was excellent for the more stationary seasons (calving, insect-relief, and winter), and these models were also spatially accurate when evaluated against the 2017-18 seasonal WAH telemetry dataset (Mean Residuals $\leq 0.12$ ). Model accuracy during the more transitory periods (spring, fall, and late summer) was good, but models for spring and fall did not predict as well to the 2017-18 data. Their good internal model accuracy (88.45 and $83.22 \%$ respectively), yet high mean residuals and large standard deviations $(0.39 \pm 0.30$ and $0.30 \pm .13$, respectively), are further evidence of the large inter-annual variability in migratory distributions of the WAH.

In a similar investigation, Nicholson et al. [7] used a Brownian-Bridge analysis to determine that caribou in

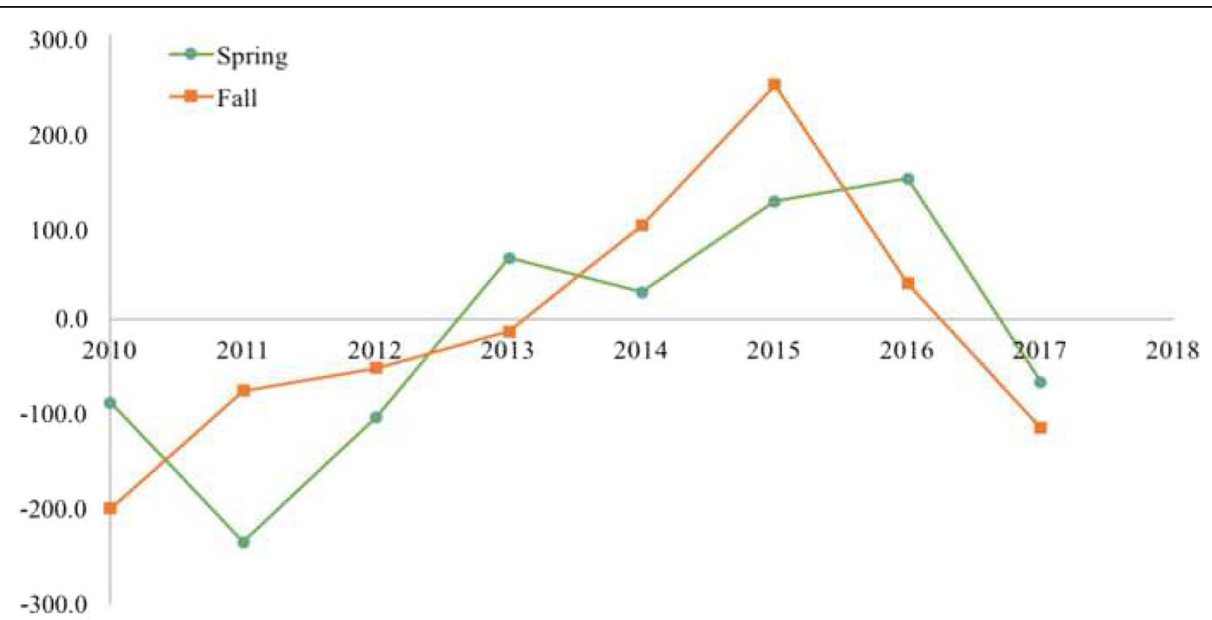

Fig. 7 Annual migratory deviation of the Western Arctic Herd from pooled modeled longitude. Chart shows the mean deviations (km) for areas predicted as presences for the spring and fall distribution models of caribou. Negative distances indicate deviation to the east, whereas positive distances indicate deviation to the west of the mean longitude for the pooled fall and spring models, respectively 


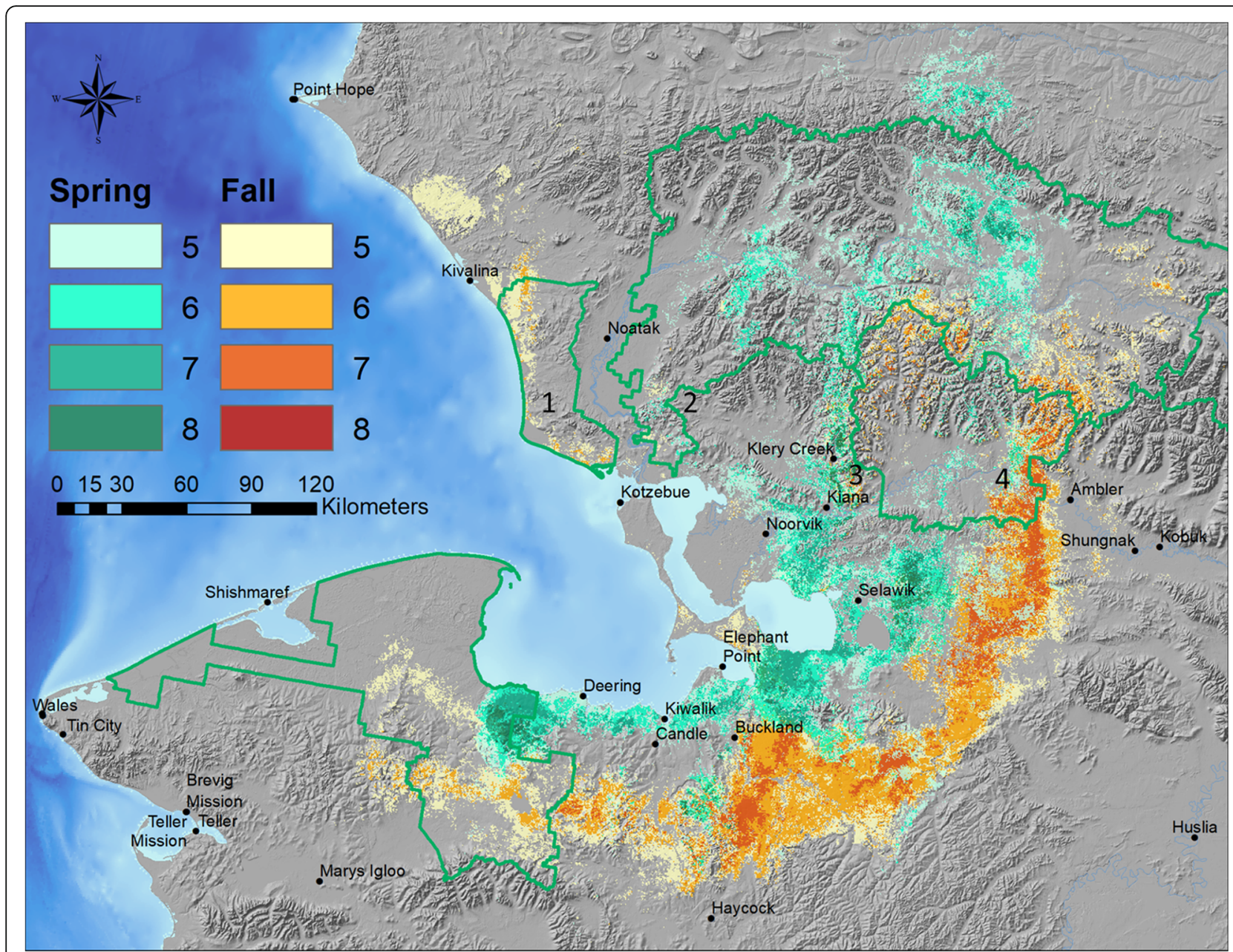

Fig. 8 Summed annual distribution models for Western Arctic Herd caribou. Composite models were developed for the spring and fall seasons. Values indicate the total number of years that each pixel was predicted as 'present.' Numbers (1-4) indicate main areas of use by caribou during the spring (green) and fall (brown) migratory seasons. National Park Service boundaries are indicated in green

the $\mathrm{CAH}$ also used a variety of routes each year, reflecting variability in individual navigation and decision making. They found, similar to our models for the WAH, that despite annual variability in distributions, specific areas were used repeatedly by caribou. These results, taken with the longitudinal and latitudinal variation from year to year, support the notion that caribou are adaptable in the location and timing of migration, and responsive to local conditions [59], while retaining a collective memory of landscapes over time [60,61]. This also implies that while certain areas may be favored by caribou over the long-term and used repeatedly, migration and ultimately harvest success in any given year will vary substantially. For example, in 2010 when the mean distribution of the WAH in fall was farthest to the east, communities around Kotzebue Sound (e.g., Noatak, Kiana, and Selawik) were unable to harvest any caribou that year [34]. Since then, the mean longitude of caribou during migration has trended to the westward extreme before returning to the mean during the final year of our study. Successful management of the WAH should recognize this full range of geographic potential, while focusing conservation efforts on the most-frequently used migratory areas outlined above.

\section{Climate}

Based on the variable importance rankings and partial dependence plots for individual predictors (Table 1, Fig. 2, Additional file 1), WAH distribution during spring migration was largely predicted by 4 climatic variables (winter precipitation, PET, fall temperature, and snow-free date) all of which help to determine snow conditions across the region during migration. Winter precipitation and PET were important predictors in both spring and fall, and migrating caribou were predicted to occur in areas with low to moderate levels of winter precipitation and moderate PET. The importance of potential evapotranspiration in all of the seasonal models highlights a 
Table 3 Land cover selection rankings for modeled WAH caribou distributions

\begin{tabular}{|c|c|c|c|c|c|c|c|c|c|}
\hline Landcover Type & $\begin{array}{l}\text { Available } \\
\text { Area }\end{array}$ & $\begin{array}{l}\text { Spring } \\
\text { Use }\end{array}$ & $\begin{array}{l}\text { Spring Mean } \\
\text { Use }\end{array}$ & $\begin{array}{l}\text { Spring } \\
\text { Selection }\end{array}$ & $\begin{array}{l}\text { Spring Mean } \\
\text { Selection }\end{array}$ & $\begin{array}{l}\text { Fall } \\
\text { Use }\end{array}$ & $\begin{array}{l}\text { Fall Mean } \\
\text { Use }\end{array}$ & $\begin{array}{l}\text { Fall } \\
\text { Selection }\end{array}$ & $\begin{array}{l}\text { Fall Mean } \\
\text { Selection }\end{array}$ \\
\hline Dwarf Shrub & 304,000 & 34,172 & 20,801 & 1.00 & 1.00 & 35,719 & 14,808 & 0.89 & 0.89 \\
\hline Herbaceous (Mesic) & 276,234 & 32,774 & 19,888 & 1.05 & 1.05 & 17,377 & 6460 & 0.48 & 0.42 \\
\hline Tussock Tundra & 126,671 & 25,711 & 14,883 & 1.80 & 1.69 & 48,779 & 20,615 & 2.92 & 2.93 \\
\hline Spruce Forest & 87,892 & 2358 & 1863 & 0.24 & 0.32 & 5403 & 2582 & 0.47 & 0.51 \\
\hline Tall Shrub & 21,372 & 2940 & 2052 & 1.22 & 1.46 & 5173 & 2452 & 1.84 & 2.12 \\
\hline $\begin{array}{l}\text { Freshwater or } \\
\text { Saltwater }\end{array}$ & 19,411 & 1018 & 617 & 0.46 & 0.45 & 1228 & 701 & 0.48 & 0.68 \\
\hline Mixed Forest & 18,670 & 132 & 127 & 0.06 & 0.10 & 332 & 203 & 0.14 & 0.18 \\
\hline Lichen & 11,674 & 1072 & 681 & 0.81 & 0.85 & 1284 & 520 & 0.84 & 0.86 \\
\hline Deciduous Forest & 11,452 & 257 & 197 & 0.20 & 0.27 & 337 & 211 & 0.22 & 0.34 \\
\hline Sparse Vegetation & 9462 & 556 & 278 & 0.52 & 0.42 & 698 & 354 & 0.56 & 0.68 \\
\hline Fire Scar & 8354 & 380 & 296 & 0.40 & 0.55 & 1716 & 730 & 1.56 & 1.38 \\
\hline Bareground & 3417 & 106 & 72 & 0.27 & 0.29 & 315 & 92 & 0.70 & 0.48 \\
\hline Ice-Snow & 433 & 5 & 3 & 0.11 & 0.11 & 10 & 3 & 0.18 & 0.12 \\
\hline $\begin{array}{l}\text { Urban, Agriculture, } \\
\text { Road }\end{array}$ & 62 & 0 & 0 & 0.07 & 0.01 & 2 & 0 & 0.19 & 0.08 \\
\hline
\end{tabular}

Habitat selections are percent of each land cover type [58] predicted to be used by caribou, divided by the percent area of each land cover type available in the study area. Selected values greater than 1.0 indicate selection for a particular land cover type. Data are for the pooled spring and fall models, and means of individual annual spring and annual fall models during 2010-2017. Available and predicted use areas are in $\mathrm{km}^{2}$

strong association between the WAH and broad-scale abiotic factors that determine PET across the region, including temperature, humidity, solar radiation, wind, and biomass. This association corresponds with other results that demonstrated increasing herd size during positive (warm) phases of the PDO and a decreasing population during periods of low (cool) PDO [45]. Areas in Alaska with the lowest PET occur primarily north of the Brooks Range and on the Seward Peninsula, compared to the warmer, drier conditions more common to interior Alaska. Likewise, most of the WAH range coincides with an area of northwest Alaska that receives moderate winter precipitation $(50-120 \mathrm{~mm})$ as compared to the higher totals found at the highest elevations or in the ranges of other arctic caribou herds. Areas receiving moderate amounts of fall precipitation or cool mean annual ground temperatures were also associated with caribou distribution in fall, corresponding to a similar area encompassing the northern Seward Peninsula, western Brooks Range, and western coast where caribou occur during fall. At the local scale, when posed with a range of available conditions in the Brooks Range, caribou were predicted to occur in valleys or west-facing ridges, where PET was higher and snow cover was shallower than higher elevations and on east facing aspects.

Earlier snow free dates were also highly predictive of caribou in spring, whereas a longer growing season was predictive of caribou in fall. In contrast to PET and winter precipitation trends which vary primarily across wider scales, the tight correspondence between early snow free date and areas predicted to have been repeatedly used by caribou in spring is apparent at a much finer local scale (Additional file 1) [62]. Snow cover has previously been shown to affect the timing and habitat selection of migrating caribou as they seek out patches of emergent forage where snow has melted [23, 62, 63]. Caribou have evolved exceptionally efficient locomotion such that the energy required to move is exceeded by the amount of forage they are able to obtain from new patches of high quality forage [64]. However, sinking through deep or crusted snow increases energy expenditure exponentially, so encountering such conditions during migration could cause delays that result in phenological and geographic mismatches during calving that could ultimately lead to starvation. This may explain why caribou were not predicted to occur in areas of late snow melt (Fig. 2d) and were predicted to travel closer to the coast in spring (Fig. 8) on wind-packed snow or sea ice. To avoid poor snow conditions, spring migration is often constricted into areas where animals develop packed trails that tend to follow windswept terrain that hardens snow $[65,66]$ and aids locomotion or other areas with low snow accumulation [64].

Caribou also selected areas of tussock tundra and areas with tall shrubs during migration (Table 3) but did not select forested habitats. Tall vegetation can impede movements, reduce visibility and increase snow depth, which may account for caribou selecting tussock tundra during spring migration. This explanation runs counterintuitive to the predicted selection for tall shrubs, 
however. Tall shrubs tend to occur in riparian valleys, where caribou were often predicted to occur, so selection for this tall cover type could be coincident with other suitable environmental conditions in Brooks Range valleys. The winter model also showed caribou using areas with less than complete or shallow snow cover (Fig. 3f). Caribou may be using areas which tend to be snow free longer in fall and spring, and which have lower relative snow depths in winter, providing them with better traveling conditions and more accessible forage. Our models predicted WAH caribou to occur in areas where moderate precipitation and relatively warmer temperatures lead to earlier snow melt, and we surmise that these combine to minimize thermodynamic and nutritional stress throughout the year.

\section{Coastal influences}

We also documented a correlation between the predicted occurrence of caribou and coastal features, as evidenced by the moderate importance of the distance to coast and mean sea ice extent predictors in many of the caribou distribution models. In both the fall and spring models, we predicted caribou to occur within $160 \mathrm{~km}$ of the coast. In spring, this predicted area of occurrence was directly adjacent to the coast $(<25 \mathrm{~km})$ and spring ice on Kotzebue Sound, where snow is windswept and packed. In fall they were predicted to occur more than $35 \mathrm{~km}$ from the coast. This more inland migration would bring them through the warmer, drier areas east of Kotzebue Sound where the growing season is longer. Such a seasonal, clockwise movement may help the herd avoid recently-foraged areas while also extending forage access later into the fall. During the insect avoidance season, caribou were predicted to occur within $60 \mathrm{~km}$ of the coast, potentially to take advantage of ocean winds and cooler temperatures that keep insects at bay [67].

The predicted distribution of caribou in spring and fall also corresponded with the proximity to the mean maximum and minimum sea ice extents (Table 1, Fig. $2 \mathrm{f}$ Additional file 1). While this relationship could coincidentally stem from the existing geographic range of the WAH near two oceans, the associations between caribou and sea ice extent could also be indicative of the direct or indirect influences of sea ice on climate, land cover, and by extension, on the distribution of the WAH [68]. Sea ice loss has been shown to indirectly affect terrestrial ecosystems through changes in climate that lengthen the growing season, promote the increase of summer plant biomass (as indicated by NDVI) [69, 70] and increase the amount of fall snowfall, which in turn insulates and raises ground temperatures [69, 71]. Associations with the minimum ice extent in both spring and fall were strongest when caribou were between 450 and $750 \mathrm{~km}$ away from the ice edge, likely reflecting only the geographic position the WAH in the region. In contrast, the correlation with mean maximum sea ice in spring were evident at much closer distances, indicating the possibility of direct effects as well. Furthermore, telemetry data show that some WAH caribou even traveled over sea ice to cross Kotzebue Sound [72]. The decrease in sea ice extent in arctic Canada has caused Peary caribou to experience an increase in landscape resistance of $15 \%$ [73], so the loss of sea ice as a travel medium, much like an increase in snow depth or water content, could theoretically increase the energetic costs of migrating WAH caribou as well $[64,72]$.

\section{Human infrastructure}

We also showed that caribou were negatively associated with roads at distances less than $20-100 \mathrm{~km}$ away during the spring, calving, insect-avoidance, late summer, and winter seasons (although there was no correlation in fall), and distance to roads was among the top predictors in each of these models (Table 1). These trends may reflect the tendency of the WAH to occur in the geographic space between the Delong Mountain Transportation System (also known as the Red Dog Mine road), the road north of the community of Kobuk, and roads emanating from Nome. However, during the insect relief season, some WAH caribou were predicted to use habitat near the coast, placing them in an area closer to the Red Dog Mine road, yet they were still not predicted to occur within $20 \mathrm{~km}$ of the road (Fig. 2e). This distance towards the upper end of previously reported zones of influence by roads that extended 14-23 $\mathrm{km}[74,75]$. Wilson et al. [16] found that $30 \%$ of WAH caribou traveling within $15 \mathrm{~km}$ of the Red Dog Mine road were delayed by an average of 33 days during fall migration. Moreover, Leblond et al. [76] documented a road-displacement distance of $5 \mathrm{~km}$ and that a majority of their study population failed to cross a highway which lead to a loss of $>50 \%$ of their range. Our models are consistent with this and other research that show caribou tending not to occur near human infrastructure, including roads, communities, and developed areas [18, 77-79]. For example, the density of females and calves in the CAH was shown to be low within 4-6 $\mathrm{km}$ of linear features within the herd's calving area, although the herd did not avoid the area during other seasons [78, 80, 81].

Our models indicated a dissociation between caribou and towns during the spring, calving, insect-relief, and winter (but not fall) seasons by $20-75 \mathrm{~km}$ (Additional file 1), with distance to community ranked among the top 10 predictors of 37 in all models (Table 1). The predicted tendency for caribou to occur away from communities may be best exemplified by their absence around the community of Noatak, but is also visible in the 
immediate vicinities of Kobuk, Kiana, Noorvik, Selawik, and Kotzebue in models and telemetry records (Fig. 8). Their predicted lack of occurrence near Noatak could also be related to spruce forests found in the valley, as caribou were predicted in treeless land cover types in much greater proportion relative to their availability (Table 2). However, the potential exists for caribou to be disturbed by noise from motorized equipment and airstrips that can be detected as far as $30 \mathrm{~km}$ of communities [37, 40], and begs further investigation. In contrast, caribou were weakly associated with communities within $75 \mathrm{~km}$ distance during fall, suggesting either that caribou are either less concerned with disturbances during this season, or that following preferred habitat during the southward migration brings them closer to more communities. In other words, communities may have historically been intentionally placed within preferred fall migratory areas, but shifting migratory patterns may be altering this association. While the passage of caribou may still continue in the vicinity of anthropogenic disturbances, the timing and duration of migration can be delayed in developed areas, and broader effects on population health have not yet been demonstrated $[16,26]$.

\section{Land cover use}

Based on our environmental niche models, we found that caribou were predicted to select lowland tussock tundra, tall shrubs and herbaceous cover types in spring and fall. The selection of tussock tundra and herbaceous cover types are similar to other habitat selection research in the region, however the selection for tall shrubs runs counter to other results [27, 45]. In an analysis of caribou movement through NOAT using step-selection functions, caribou exhibited random-walk behavior, and exploited areas of tussock tundra and dwarf shrubs, while avoiding tall shrubs, rugged terrain, and rivers [27]. Such selection is consistent with caribou maximizing energetic efficiency and seeking out areas of optimal forage, namely patches of exposed lichen in warm microclimates, especially on the south side of the Brooks Range [26, 82, 83]. In fall and winter, caribou obtained $\sim 71 \%$ of their forage from lichens, whereas the next most important forage types, moss and shrubs comprised just 20\% [82]. In fact, lichens typically comprised $65-70 \%$ of the diet of migratory caribou with substantial predation pressure in Alaska [31, 82-84]. The accessibility of forage to caribou, especially as related to snow cover and fire, are factors driving movements of the WAH $[28,85]$.

Our results did not show any major influence of topographic variables (e.g., elevation, aspect, slope, terrain ruggedness) in models for any season or year. However, there was a positive relationship between occurrence and elevation above $200 \mathrm{~m}$ and an inverse relationship with terrain ruggedness. [27]. Similarly, caribou in the Porcupine Herd were shown to use corridors at higher elevations but with relatively gentle terrain, while avoiding spruce forests, steep mountains, and wet lowlands [79]. Together these results suggest that caribou follow energetically efficient courses through snow-free areas to minimize locomotive resistance and maximize available forage, while largely conforming to learned directional orientation to guide migration $[26,60]$.

\section{Conclusion}

We posit that given the influence of climate variables in our models, that rapid changes in these processes will play outsized roles in determining the trajectory of caribou in the future. Increased climatic volatility and annual shifts in migratory patterns of the WAH underscore the need to allow caribou to select among a variety of habitats in order to find the most suitable conditions in a given year or season. Strong links between caribou distribution and interacting trends in snow, PET, growing season, and sea ice are apparent in our models. As the volatility in these and other climate effects (e.g., increased fire frequency and shrubification) grows, WAH caribou migration patterns are also likely to become more variable in the future. We surmise that this could result in changing phenologies (e.g., delayed migration, increased spatial variability in calving) as a means of coping with decreasing climatic reliability. As such, the success of harvesting caribou near any given rural community in a given year may correspondingly decrease in the future as well [86].

It remains unclear whether WAH caribou are capable of adapting to rapid climatic changes or whether future predictions of a distribution contraction will occur. Some potential changes, like longer growing seasons, may aid caribou by allowing for increased energetic intake, while others, like the loss of sea ice from Kotzebue Sound and deeper, crusted snow, could make travel costlier near the coast. As a species, caribou have thus far largely adapted to an evolving suite of highly variable and changing ecological conditions, including new predators [87], changing habitat and forage quality [31], and the development of portions of their range [16]. It is possible that they may also be capable of adapting behaviorally to the threats of accelerating climate change and further limited development. However, the rates of environmental change in the Arctic are unprecedented and the ability of WAH caribou to adapt at these rapid rates should not be taken for granted.

Although we did not explicitly measure displacement, our models predicted the majority of WAH to occur in areas at least $20-100 \mathrm{~km}$ from roads and communities during all seasons except fall (Fig. 2, Additional file 1). This could have important implications for the herd 
should any of the numerous proposed roads be constructed in northwest Alaska, especially those that would bisect the documented migratory areas in the Kobuk Valley (Fig. 8). Proposed roads extending from the communities of Ambler to Kotzebue, Noatak or the Red Dog Mine could have major consequences for caribou because these corridors would bisect all of the main migratory regions. While a proposed road to access the Ambler mining district stops short of much of the core WAH migratory area, it would cut directly through a core area used by caribou during the winter (Fig. 3f). In addition to potential disruptions to migration $[16,21]$ and the effects of windborne dust $[88,89]$ resulting from industrial traffic, an associated increase in hunter access to migratory areas could have far more detrimental effects on caribou populations, should this or other new roads be publically accessible (see [26, 90]). Given the extensive climatic and anthropogenic disturbances threatening the Western Arctic Herd, we echo the call for comprehensive management planning that recognizes and conserves a variety of migratory areas to buffer caribou from environmental volatility as part of a long-term persistence strategy for caribou in the Arctic [7, 79].

\section{Additional file}

Additional file 1: Partial dependence plots for the top 30 variables in each of the seasonal predictive models for caribou in the Western Arctic Herd. These are model-based simulations that chart the non-linear relationship of the response over the range of each predictor variable while controlling for the other predictors. (DOCX $533 \mathrm{~kb}$ )

\section{Abbreviations}

AUC: Area Under the Curve; BELA: Bering Land Bridge National Preserve; CAH: Central Arctic Herd; CAKR: Cape Krusenstern National Monument; GAAR: Gates of the Arctic National Park and Preserve; GPS: Global Positioning System; KOVA: Kobuk Valley National Park; NDVI: Normalized Difference Vegetation Index; NOAT: Noatak National Preserve; PDO: Pacific Decadal Oscillation; PET: Potential Evapo-transpiration; RIO: Relative Index of Occurrence; WAH: Western Arctic Herd

\section{Acknowledgements}

GPS collar deployments are a collaborative effort with the Alaska Department of Fish and Game (ADFG), Bureau of Land Management, National Park Service, US Fish and Wildlife Service and local area schools. We thank M. Cameron for helpful discussions regarding the models and caribou ecology. We also appreciate reviews of the original manuscript by $\mathrm{A}$. Hansen, J. Rasic, and E. Wald.

\section{Authors' contributions}

AB developed, analyzed, and interpreted all spatial models and datasets, and was the primary author of the manuscript. KJ conducted animal capture and collaring, coordinated telemetry data collection, and contributed significantly to the design of the study, interpretation of data, and the writing of the manuscript. Both authors read and approved the final manuscript.

\section{Funding}

This work was funded by the National Park Service (NPS).

\section{Availability of data and materials}

The datasets used and/or analyzed during the study are archived at: https:// irma.nps.gov/DataStore/Reference/Profile/2260262.
Ethics approval and consent to participate

Collaring of caribou was approved by the State of Alaska's Animal Care and Use Committee (ACUC) protocol \#2012-031R.

\section{Consent for publication}

Not applicable.

\section{Competing interests}

The authors declare that they have no competing interests.

Received: 13 December 2018 Accepted: 16 May 2019

Published online: 06 June 2019

\section{References}

1. Fryxell JM, Sinclair ARE. Causes and consequences of migration by large herbivores. Trends Ecol Evol. 1988;3(9):237-41.

2. Jachowski DS, Singh NJ. Toward a mechanistic understanding of animal migration: incorporating physiological measurements in the study of animal movement. Conservation Physiol. 2015;3:1-12

3. McClure ML, Hansen A, Inman R. Connecting models to movements: testing connectivity model predictions against empirical migration and dispersal data. Landsc Ecol. 2016;31:1419-32.

4. Panzachhi M, Van Moorter B, Strand O, Saerens M, Kivimaki I, St Clair C, et al. Predicting the continuum between corridors and barriers to animal movements using step selection functions and randomized shortest paths. J Anim Ecol. 2016;85:32-42.

5. Aikens EO, Kauffman MJ, Merkle JA, Dwinnell SPH, Fralick GL, Monteith KL. The greenscape shapes surfing of resource waves in a large migratory herbivore. Ecol Lett. 2017;20:741-50.

6. Fryxell JM. Forage quality and aggregation by large herbivores. Am Nat. 1991;138:478-98.

7. Nicholson KL, Arthur SM, Horne JS, Garton EO, Del Vecchio A. Modeling caribou movements: seasonal ranges and migration routes of the Central Arctic herd. PLoS One. 2016;11(4) https://doi.org/10.1371/journal.pone. 0150333.

8. Sawyer H, Lindzey F. Jackson Hole Pronghorn Study. Laramie, WY: Wyoming Cooperative Fish \& Wildlife Research Unit; 2000. p. 1-40.

9. Smith BL, Robbins RL. Migrations and management of the Jackson elk herd Washington, D.C.: United States Department of Interior; 1994. 66 pp

10. Carrel WK, Ocknefels RA, Schweinsburg RE. An evaluation of annual migration patterns of the Paunsaugunt mule deer herd between Utah and Arizona. Phoenix: Arizona Game \& Fish; 1999.

11. Sawyer $H$, Kauffman MJ, Middleton AD. A framework for understanding semi-permeable barrier effects on migratory ungulates. J Appl Ecol. 2012;50:68-78

12. Geremia C, White P, Wallen R, Watson F, Treanor J, Borkowski J, et al. Predicting bison migration out of Yellowstone National Park using Bayesian models. PLoS One. 2011;6(2):1-9.

13. Mauer EJ. Moose migration: Northeast Alaska to western Yukon territory. Canada Alces. 1998;34:75-81.

14. Fancy SG, Pank LE, Whitten KR, Regelin WL. Seasonal movements of caribou in arctic Alaska as determined by satellite. Can J Zool. 1989;67:644-50.

15. Avgar T, Mosser A, Brown GS, Fryxell JM. Environmental and individual drivers of animal movement patterns across a wide geographical gradient. J Anim Ecol. 2013;82(1):96-106

16. Wilson RR, Parrett LS, Joly K, Dau JR. Effects of roads on individual caribou movements during migration. Biol Conserv. 2016;195:2-8.

17. Klein DR. Reaction of reindeer to obstructions and disturbances. Science. 1971;173:393-8

18. Bolger DT, Newmark WD, Morrison TA, Doak DF. The need for integrative approaches to understand and conserve migratory ungulates. Ecol Lett. 2008;11:63-77.

19. Prokopenko CM, Boyce MS, Avgar T. Extent-dependent habitat selection in a migratory large herbivore: road avoidance across scales. Landsc Ecol. 2017;32(2):313-25

20. Cameron RD, Reed DJ, Dau J, Smith WT. Redistribution of calving caribou in response to oil field development on the Arctic slope of Alaska. Arctic. 1992;45(4):338-42.

21. Wolfe SA, Griffith B, Gray Wolfe CA. Response of reindeer and caribou to human activities. Polar Res. 2000;19(1):63-73. 
22. Mallory CD, Boyce MS. Observed and predicted effects of climate change on Arctic caribou and reindeer. Environ Rev. 2018;26:13-25.

23. Pruitt WO Jr. Snow as a factor in the winter ecology of the barren ground caribou (Rangifer arcticus). Arctic. 1959;12(3):158-79.

24. Sharma S, Couturier S, Côté SD. Impacts of climate change on the seasonal distribution of migratory caribou. Glob Chang Biol. 2009;15(10):2549-62.

25. Berger J. The last mile: how to sustain long-distance migration in mammals. Conserv Biol. 2004;18:320-31.

26. Bergerud AT, Jakimchuk RD, Carruthers DR. The buffalo of the north: Caribou (Rangifer tarandus) and human developments. Arctic. 1984;37(1):7-22.

27. Fullman TJ, Joly K, Ackerman A. Effects of environmental features and sport hunting on caribou migration in northwestern Alaska. Movement Ecology. 2017;5(4):1-11

28. Joly $K$, Jandt RR, Klein DR. Decrease of lichens in Arctic ecosystems: the role of wildfire, caribou, reindeer, competition and climate in North-Western Alaska. Polar Res. 2009;28(3):433-42.

29. Horne JS, Craig T, Joly K, Stout GW, Cebrian MR, Garton EO. Population characteristics, space use and habitat selection of two non-migratory caribou herds in Central Alaska, 1994 - 2009. Rangifer. 2015;34(1):1-19.

30. Western Arctic Caribou Herd increases after years of decline [press release] Juneau AK: Alaska department of fish and game, January 10, 20182018

31. Joly K, Cole MJ, Jandt RR. Diets of overwintering caribou, Rangifer tarandus, track decadal changes in arctic tundra vegetation. Can Field-Nat. 2007;121(4):379-83.

32. Dau J. Units 21D, 22A, 22B, 22C, 22D, 22E, 23, 24 and 26A. Juneau, Alaska: Alaska Department of Fish and Game; 2013.

33. Joly K, Cameron MD. Caribou vital sign annual report for the Arctic Network Inventory and Monitoring Program: September 2016-August 2017. Fort Collins, CO: National Park Service; 2017.26 pp.

34. Brubaker M, Bell JF, Berner J, Black M, Chavan R, Smith J, et al. Climate change in Noatak, Alaska: strategies for community health, ANTHC. Available from:https://anthc.org/what-we-do/community-environment-and-health/ center-for-climate-and-health/climate-health-3/ Accessed: 10 Oct 2018; 2011.

35. Fix P, Ackerman A. Noatak National Preserve Sport Hunter Survey: Caribou Hunters from 2010-2013. Fort Collins, CO, USA: National Park Service; 2015.

36. Halas G. Caribou migration, subsistence hunting, and user group conflicts in Northwest Alaska: a traditional knowledge perspective. Fairbanks, AK: Master's thesis. In: University of Alaska Fairbanks; 2015.

37. Sitinchcomb TR. Social-ecological soundscapes: examining aircraft-harvestercaribou conflict in Arctic Alaska. Fairbanks, AK. In: USA: University of Alaska Fairbanks; 2017

38. Banfield AW. The relationship of caribou migration behavior to pipeline construction. In: Geist V, Walther F, editors. The behavior of ungulates and its relation to management. 2. Morges, Switzerland: International Union for the Conservation of nature; 1974. p. 797-804.

39. Dau JR, Cameron RD. Effects of a road system on caribou distribution during calving. Rangifer 1986 (Spec Issue). 1:94-101.

40. Barber JR, Crooks KR, Fistrup KM. The costs of chronic noise exposure for terrestrial organisms. Trends Ecol Evol. 2010;25(3):180-9.

41. Tape KD, Hallinger M, Welker JM, Ruess RW. Landscape heterogeneity of shrub expansion in Arctic Alaska. Ecosystems. 2012:15:711-24.

42. Walsh JE, Overland JE, Groisman PY, Rudolf B. Ongoing climate change in the Arctic. Ambio. 2011:40:6-16.

43. Knowles N, Dettinger D, Cayan DR. Trends in snowfall versus rainfall in the western United States. J Clim. 2006:19:4545-59.

44. McAfee SA, Walsh JE, Rupp T. Statistically downscaled projections of snow/ rain partitioning for Alaska. Hydrol Process. 2013:28:3930-46.

45. Joly K, Klein DR, Verbyla DL, Rupp TS, Chapin FS III. Linkages between largescale cimate patterns and the dynamics of Arctic caribou populations. Ecography. 2011;34:345-52

46. Macias-Fauria M, Post E. Effects of sea ice on Arctic biota: an emerging crisis discipline. Biol Lett. 2018;14(3). https://doi.org/10.1098/rsbl.2017.0702.

47. Friedman J. Greedy function approximation: a gradient boosting machine. Ann Stat. 2001:29(5):1189-232.

48. Elith J, Leathwick JR, Hastie T. A working guide to boosted regression trees. J Anim Ecol. 2008;77:802-13.

49. Hastie T, Tibshirani R, Friedman JH. The elements of statistical learning: data mining, inference, and prediction, vol. 763. New York, NY, USA: SpringerVerlag; 2001

50. Evans JS, Murphy MA, Holden ZA, Cushman SA. Modeling species distribution and change using random Forest. In: Drew CA, YFW FH, editors.
Predictive species and habitat modeling in landscape ecology. Berlin: Springer; 2011. p. 139-60.

51. Kirkwood C, Cave M, Beamish D, Grebby S, Ferreira A. A machine learning approach to geochemical mapping. J Geochem Explor. 2016;167:49-61.

52. Breiman L. Statistical modeling: the two cultures. Stat Sci. 2001;16(3):199-231.

53. Baltensperger AP. Using interactions among species, landscapes, and climate to inform ecological niche models: a case study of American marten (Martes americana) distribution in Alaska. In: Huettmann F, Humphries G, Magness D, editors. Machine learning as an effective tool for modern ecology and sustainable natural resource management. New York: Springer; 2018.

54. De'ath G, Fabricius KE. Classification and regression trees: a powerful yet simple technique for ecological data analysis. Ecology. 2000;81(11):3178-92.

55. Steinberg D. Dan Steinberg's Blog [Internet]. San Diego: Salford Systems, Inc:; 2006. [10 October 2016]. Available from: https://www.salford-systems. com/blog/dan-steinberg/modeling-tricks-with-treenet-treating-categoricalvariables-as-continuous

56. Hutchinson GE. Concluding remarks. Cold Spring Harbour Symposium on Quantitative Biology. 1957:22:415-27.

57. Jimenez-Valverde A, Lobo JM. Threshold criteria for conversion of probability of species presence to either-or presence-absence. Acta Oecologica-Int J Ecol. 2007;31(3):361-9.

58. Vegetation map and classification: Northern, western, and interior Alaska second edition [internet]. Alaska Center for Conservation Science, University of Alaska Anchorage, Alaska. 2016 [cited July 1, 2018].

59. Le Corre M, Dussault C, Côté SD. Weather conditions and variation in timing of spring and fall migrations of migratory caribou. J Mammal. 2017;98(1):260-71.

60. Jesmer BR, Merkle JA, Goheen JR, Aikens EO, Beck J, Courtemanch A, et al. Is ungulate migration culturally transmitted? Evidence of social learning from translocated animals. Science. 2018;361:1023-5.

61. Sasaki T, Biro D. Cumulative culture can emerge from collective intelligence in animal groups. Nat Commun. 2017. https://doi.org/10.1038/ ncomms15049.

62. Macander MJ, Swingley CS, Joly K, Raynolds MK. Landsat-based snow persistence map for Northwest Alaska. Remote Sens Environ. 2015;163:23-31.

63. Griffith B, Douglas D, Walsh N, Young D, McCabe T, Russel D, et al. Section 3: the porcupine Caribou herd. 2002. Contract No.: 2002-0001:8-38.

64. Fancy SG, White RG. Energy expenditures for locomotion by barren-ground caribou. Can J Zool. 1987:65:122-8.

65. Collins WB, Smith TS. Effects of wind-hardened snow on foraging by reindeer (Rangifer tarandus). Arctic. 1991;44:217-22.

66. Henshaw J. The activities of the wintering caribou in northwestern Alaska in relation to weather and snow conditions. Int J Biometeorol. 1968;12:21-7.

67. Service NP. State of the park report for Bering land bridge National Preserve. Washington, D.C.: National Park Service; 2016.

68. Hinzman LD, Deal CJ, McGuire AD, Mernild SH, Polyakov IV, Walsh JE. Trajectory of the Arctic as an integrated system. Ecol Appl. 2013;23(8):1837-68.

69. Bhatt U, Walker D, Raynolds MK, Comiso JC, Epstein HE, Jia G, et al. Circumpolar Arctic tundra vegetation change is linked to sea ice decline. Earth Interations. 2010;14:1-20.

70. Post E, Bhatt U, Bitz CM, Brodie JF, Fulton TL, Hebblewhite M, et al. Ecological consequences of sea-ice decline. Science. 2002;341:519-24.

71. Hinzman LD, Viereck LA, Adams PC, Romanovsky VE, Yoshikawa K. Climate and permafrost dynamics of the Alaskan boreal forest. In: Chapin FS, Oswood MW, Cleve KV, Viereck LA, Verbyla DL, editors. Alaska's changing boreal forest. New York: Oxford University Press; 2006. p. 39-61.

72. Joly K. Sea ice crossing by migrating caribou, Rangifer tarandus, in Northwest Alaska. Can Field-Nat. 2012;126(3):217-20.

73. Jenkins DA, Lecomte N, Schaefer JA, Olsen SM. Loss of connectivity among island-dwelling Peary caribou following sea ice decline. Biol Lett. 2016:12(9):20160235.

74. Boulanger J, Poole G, Gunn A, Wierzchowski J. Estimating the zone of influence of industrial developments on wildlife: a migratory caribou Rangifer tarandus groenlandicus and diamond mine case study. Wildl Biol. 2012;18:164-79.

75. Plante S, Dussault C, Richard JH, Côté SD. Human disturbance effects and cumulative habitat loss in endangered migratory caribou. Biol Conserv. 2018;224:129-43.

76. Leblond M, Dussault C, Ouellet JP. Avoidance of roads by large herbivores and its relation to disturbance intensity. J Zool. 2013;289:32-40. 
77. Antonnen M, Kumpula J, Colpaert A. Range selection by semi-domesticated reindeer (Rangifer tarandus tarandus) in relation to infrastructure and human activity in the boreal forest environment, northern Finland. Arctic. 2011:64(1):14.

78. Whitten KR, Cameron RD, editors. Distribution of caribou calving in relation to the Prudhoe Bay Oilfield. Caribou and human activity; 1985: Canadian Wildlife Service.

79. Whitten KR, Fancy SG. Movement patterns of the Porcupine Caribou Herd in relation to oil development. Juneau, AK: Alaska Department of Fish and Game; 1991.i-44.

80. Cameron RD, Smith W, White RG, Griffith B. Section 4: the Central Arctic Caribou herd. Contract No. 2002;2002-0001:38-46.

81. Gunn A, Miller FL. Traditional behaviour and fidelity to caribou calving grounds by barren-ground caribou. Rangifer. 1986; Special Issue No. 1:151-158.

82. Joly K, Cameron MD. Early fall and late winter diets of migratory caribou in Northwest Alaska. Rangifer. 2018;38(1):27-38.

83. Joly K, Wasser SK, Booth R. Non-invasive assessment of the interrelationships of diet, pregnancy rate, group composition, and physiological and nutritional stress of barren-ground caribou in late winter. PLoS One. 2015;10(6):e0127586. https://doi.org/10.1371/journalpone.

84. Gustine DD, Barboza PS, Lawler JJ, Adams L, Parker KL, Arthur SM, et al. Diversity of nitrogen isotopes and protein status in caribou: implications for monitoring northern ungulates. J Mammal. 2012;93(3):778-90.

85. Saperstein LB. Winter forage selection by barren-ground caribou: effects of fire and snow. Rangifer. 1996;9(Special Issue):237-8.

86. Kofinas GP, Chapin FS III, BurnSilver S, Schmidt JI, Fresco N, Kielland K, et al. Resilience of Athabascan subsistence systems to interior Alaska's changing climate. Can J For Res/Rev Can Rech For. 2010;40:1347-59.

87. Schaeeffer JA, Mahoney SP. Diets of overwintering caribou, Rangifer tarandus, track decadal changes in arctic tundra vegetation. Can Field-Nat. 2007;121(4):379-83.

88. Chen W, LeBlanc SG, White HP, Prevost C, Milakovic B, Rock C, et al. Does dust from arctic mines affect caribou forage? J Environ Prot. 2017;8:258-76.

89. Hasselbach L, Hoef JMV, Ford J, Neitlich P, Crecelius E, Berryman S, et al. Spatial patterns of cadmium and lead deposition on and adjacent to National Park Service lands near Red Dog Mine, Alaska: NPS Final Report Kotzebue, AK: National Park Service Technical Report NRTR-2004-45; 2004.59 pp.

90. Guettabi M, Greenerg J, Little J, Joly K. Evaluating potential economic effects of an industrial road on subsistence in north-Central Alaska. Arctic. 2016;69(3):305-17.

91. Pastick N, Jorgenson TM, Wylie BK, Johnson KD, Finley AO. Distribution of near-surface permafrost in Alaska: estimates of present and future conditions. Remote Sens Environ. 2015;168:301-15.

92. Rogers TS, Walsh JE, Leonawiscz M, Lindgren M. Arctic Sea ice: use of observational data and model hindcasts to refine future projections of ice extent. Polar Geogr. 2015;38:22-41.

\section{Publisher's Note}

Springer Nature remains neutral with regard to jurisdictional claims in published maps and institutional affiliations.

\section{Ready to submit your research? Choose BMC and benefit from:}

- fast, convenient online submission

- thorough peer review by experienced researchers in your field

- rapid publication on acceptance

- support for research data, including large and complex data types

- gold Open Access which fosters wider collaboration and increased citations

- maximum visibility for your research: over $100 \mathrm{M}$ website views per year

At $\mathrm{BMC}$, research is always in progress.

Learn more biomedcentral.com/submissions 